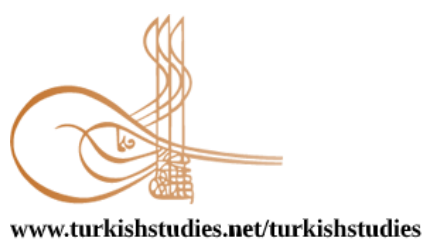

www.turkishstudies.net/turkishstudies
Turkish Studies

eISSN: $1308-2140$

Research Article / Araștırma Makalesi

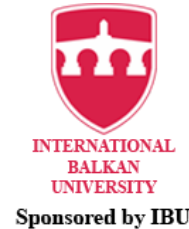

Sponsored by IBU

\title{
Bir Sanatçı, İki Minber: Manisa Ulu Cami (1376) ve Bursa Ulu Cami (1399) Minberleri Üzerinden Düşünceler
}

One Artist, Two Minbars: Reflections on the Minbars of Manisa Ulu Mosque (1376) and Bursa Ulu Mosque (1399)

\author{
Sema Gündüz Küskü*
}

\begin{abstract}
Two of the principalities that emerged in different political and social environments are the Ottomans (1299-1923) and Sarukhanids (1300-1410). Although these two principalities sometimes form alliances, they are in constant competition with each other. This mode of rivalry has affected the artist choices of the sultans as well as the construction activities. Moreover, the artist preferences of the patrons were accepted as a display of power and a means of self-expression. For this reason, it is significant that Bayezid I had the minbar built by the same artist 23 years after İshak Çelebi's, even though their power and balance of power were different. The name of this Antep origin artist is "amel-i el Hac Muhammed bin Abd-ul Aziz ibn-ül-Daki el- Ayintabi". When we compare the quality, monumentality and craftsmanship of these two minbars which are present in the mosques which were built under the patronage of İshak Çelebi (1359?-1388) and Bayezid I (1389-1402) it is possible to question the power of the aforementioned rulers of the era. As it is known, minbars symbolize the most political side of mosques because of the khutba being read on them. If this building is a sultan's mosque located in the center of the capital, as in the case of Bursa Ulu and Manisa Ulu Mosques, the political aspect of the minbar turns into an "image". For this reason, the monumentality and fine workmanship of the minbars are very important. In addition to monumentality and fine workmanship, another important data on these minbars that refers to the "image" are patrons inscriptions. In addition to the minbars, the architectural elements of the mosques (such as the plan scheme, material-technical features, facade designs and monumentality) reflect the features that will document the strong political personality of the period. For this reason, our aim is to try to read the historical and political structure of the period by examining the reflection of power on architecture through these two minbars.
\end{abstract}

Structured Abstract: The Minbars of Manisa Ulu Mosque which was built in the reign of Sarukhanids and Bursa Ulu Mosque which was built in the reign of Ottomans, were made by an artist of Antep origin, named "amel-i el Hac Muhammed bin Abd-ul Aziz ibn-ül-Daki el- Ayintabi". When we compare the quality, monumentality and craftsmanship of these two minbars which are present in the mosques which were built under the patronage of İshak Çelebi and Bayezid I it is possible to question the power of the aforementioned rulers of the era.

\footnotetext{
* Doç. Dr., İzmir Katip Çelebi Üniversitesi, Sosyal ve Beşeri Bilimler Fakültesi, Türk-İslam Arkeolojisi Bölümü Assoc. Prof. Dr., Izmir Katip Celebi University, Faculty of Humanities and Social Sciences, Department of Turk-Islamic Archeology

Checked by plagiarism software

CC BY-NC 4.0 
Muzafferüddin İshak Bey/Çelebi is the third sultan to ascend to the throne after the founder Saruhan Bey and Sultan İlyas Çelebi. İshak Çelebi is the first and only sultan in whose reign a külliye was built in the capital Manisa. This reveals the idea that the külliye of İshak Çelebi, which constitutes the center of the city, is a building complex that symbolizes the "existence claim" of the Sarukhanid rule. Bayezid I is the fourth sultan who ascended the throne after Osman I, Orhan and Murad I. Bayezid I, on the other hand, followed the tradition like the two previous sultans and had a social complex built in the capital Bursa. Apart from the complex, he had a mosque and a covered bazaar built in Bursa. However Bayezid, placed his building which is the third mosque of the Ottoman sultans in the capital Bursa, outside the city walls, in the heart of the city, unlike the previous sultan mosques inside the city walls. It is possible to assert that Bayezid I by building a mosque of that quality fulfill the lack of a "Great Mosque" that would define the city center and symbolize the power of the sultan. By doing this he left his mark on the capital. This preference suggests that Bayezid I as the third sultan of a principality that had put forward its "existence claim" tried to emphasize his own power.

The minbar of the Manisa Ulu Mosque made of ebony, dated 1376, is one of the most important examples of the kundekari technique from the principalities period. The most important feature that make this minbar different is the inlaid decorations of the door wings. The inlays only in this part of the minbar are in large and small pieces. Bursa Ulu Mosque minbar, which is made of walnut wood and dated 1399, was also made with the kundekari technique. Unlike the Manisa minbar, the inlay technique was applied with a fine workmanship on the side surfaces of the Bursa minbar, the under-throne sections and the decoration borduries surrounding the patrons inscription. That's why this minbar, overshadows all other examples of the period with its monumentality/scale, fine inlay and the intensity of the hem-stitch technique.

As it is known, minbars symbolize the most political side of mosques because of the khutba being read on them. If this building is a sultan's mosque located in the center of the capital, as in the case of Bursa Ulu and Manisa Ulu Mosques, the political aspect of the minbar turns into an "image". The most important data on these minbars, which refer to the "image" apart from fine workmanship, are patrons inscriptions. Despite the plain and unpretentious name of Ishak Bey on the minbar of Manisa Ulu Mosque, the name of Bayezid I was written on the minbar of Bursa Ulu Mosque in a much larger and more ostentatious way. In this way, the name of the sultan was predominant on the door front of the minbar. This difference is proof that Bayezid I interpreted the minbar, which was the most monumental work of the period, as an "image of sovereignty". In fact, this is the most important document displaying the "strong personality" of the period, which is also supported by the architectural and artistic features of the mosques. Another strong patron effect reflected on the minbars is evident in the artist's inscriptions. Interestingly, the artist Daki has written his name on three different spots which can be easily seen from all directions, on the Manisa minbar. On the other hand, there is only one artist inscription on the Bursa minbar, and this inscription is almost compressed to the point where it is located. It is possible that Sultan Bayezid prevented the artist's name from being written more than his own name on the minbar, which is an image of sovereignty. In other words, it can be suggested that this situation is a result of the desire of the patron which is in power.

The historical background actually reveals the political power (and the economy that was shaped accordingly) of these two principalities. Political and economic power, on the other hand, brings the sultanic ostentation on architecture with itself. In that case, the result that emerged, supported by other architectural elements (such as plan scheme, material-technical properties, facade designs and monumentality) besides the minbars of the mosques, is the strong political personality of Bayezid I and his desire to show it. The strong personality and power of Bayezid I, which was tried to be resolved through minbars and architectural features, is also supported by the political history of the period. Sarukhanid Principality was first seized by Bayezid I. The fact that the Sultan employed the artist Daki in his own structure after this conquest indicates that it was almost considered as a document of this conquest. This proposition also supports the idea that the minbar of Bursa Ulu Mosque, which draws attention with its artistic delicacy from these two examples, which were built by the same artist 23 years apart, displays the potent personality and power of the period. As a result, considering that political success affects economic power and economic power is shown in art/architecture, it can be accepted that the mentioned minbars are almost a "document" about the political environment of the period. In other words, this historical process, which historians refer to as the "centralization and imperialization movement" attributed to Bayezid I, is also in complience with the artistic inference reached through minbars.

Keywords: History of Art, Minbar, Bursa Ulu Mosque, Manisa Ulu Mosque, Ishak Celebi, Bayezid I. 
Öz: Farklı etkenlerin biçimlendirdiği siyasal ve sosyal ortamda ortaya çıkan beyliklerden konumuzu oluşturan ikisi, Osmanoğulları (1299-1923) ile Saruhanoğulları'dır (1300-1410). Kuruldukları ilk andan itibaren zaman zaman ittifaklar kuran bu beyliklerin birbirleri ile sürekli bir rekabet halinde oldukları bilinir. Bu rekabet dünyası imar faaliyetlerinin yanı sıra sultanların sanatçı seçimlerini de etkilemiştir. Hatta banilerin sanatçı tercihleri güç gösterisi ve kendini ifade etme aracı olarak da kabul edilmiştir. Bu nedenle, güçleri ve başta bulundukları dönemlerin güç dengeleri farklı olsa da, I. Bayezid'in minberini, İshak Çelebi'nin minberinden 23 yıl sonra, aynı sanatçıya yaptırmış olması anlamlıdır. Bu Antep kökenli sanatçının ismi "amel-i el Hac Muhammed bin Abd-ul Aziz ibn-ül-Daki el- Ayintabi" dir. İshak Çelebi (1359?-1388) ve I. Bayezid'in (13891402) baniliğindeki camilere ait olan bu iki minber kalite, anıtsallık ve iş̧̧ilik açısından karşılaştırıldığında dönemin daha güçlü kimliğinin sorgulanmasına olanak sağlar. Bilindiği üzere minberler, üzerlerinde hutbe okunması nedeniyle camilerin en siyasi tarafını simgeler. Eğer bu camiler, Bursa Ulu Cami ve Manisa Ulu Cami örneklerinde olduğu gibi başkentin merkezinde konumlandırılan birer sultan camisi ise minberin siyasi yönü "imgeye" dönüşür. Bu nedenle minberlerin anıtsallığı ve sanatsal inceliği çok önemlidir. Anıtsallık ve sanatsal inceliğe ek olarak, bu minberlerde "imgeye" gönderme yapan bir diğer önemli veri ise bani kitabeleridir. Sözü edilen camilerin minberleri dışında diğer mimari unsurları da (plan şeması, malzeme-teknik özellikleri, cephe tasarımları ve anıtsallıkları gibi) dönemin güçlü siyasi kiş̧iliğini belgeleyecek özellikler yansıtır. Bu nedenle amacımız, gücün mimariye yansıma şeklini bu iki minber aracılı̆̆ıyla irdeleyerek, sözü edilen iki beylik kapsamında dönemin tarihsel ve siyasi yapısını okumaya çalışmaktır.

Anahtar Kelimeler: Sanat Tarihi, Minber, Bursa Ulu Cami, Manisa Ulu Cami, İshak Çelebi, I. Bayezid.

\section{Giriş}

Anadolu Selçuklularının uç bölgelere yerleştirdikleri beyler ya yerleştikleri bölgelerde ya da Selçuklu sultanları tarafından kendilerine ikta olarak verilen merkezlerde bağımsızlıklarını ilan etmişlerdir. Anadolu'nun Selçuklulardan önceki hâkimi Bizans, Haçlılar, Selçuklu dönemi beylikleri ve Anadolu'nun içlerine kadar girerek Selçukluların çöküşüne sebep olan Moğollar gibi farklı etkenlerin biçimlendirdiği siyasal ve sosyal ortamda ortaya çıkan bu beyliklerden ikisi, Söğüt'ü merkez alarak Sakarya bölgesine yerleşmiş bulunan ve küçük bir beylikten büyük bir İmparatorluğa dönüşen Osmanlılar (1299-1923) ile Manisa ve çevresinde egemen olan Saruhanoğulları'dır (13001410).

Konumuz açısından bu iki beyliği diğer beyliklerden ayrıcalıklı kılan ise I. Bayezid (13891402) ve İshak Çelebi (1359?-1388) olmak üzere bu beyliklerin sultanları/beyleri tarafından inşa edilen iki önemli yapıda aynı sanatçı ismine rastlanılmasıdır. Mimari özellikleriyle öne çıkan Saruhanoğullarına ait Manisa Ulu Cami (1366) ile Osmanlılara ait Bursa Ulu Cami'nin (1399) minberleri, "amel-i el Hac Muhammed bin Abd-ul Aziz ibn-ül-Daki el- Ayintabi" isimli Antep kökenli sanatçıya yaptırılmıştır (Sönmez, 1995, s. 40, 352). Yeni kurulmakta olan beyliklerin kendilerini meşrulaştırma arzusu içerisine girdikleri böyle bir dönemde, aynı sanatçıya yaptırılmış olan iki minber ile camileri kalite ve üslup açısından değerlendirildiğinde dönemin daha güçlü kimliğinin sorgulanmasına olanak sağlar. Amacımız, gücün mimariye yansıma şeklini bu iki minber aracılığıyla irdeleyerek, sözü edilen iki beylik kapsamında dönemin tarihsel ve siyasi alt yapısını okumaya çalışmaktır. Bir anlamda da yöneticilerinin "sultan" ününü kullandığı her iki beylik kapsamında "bey-sultan" kavramını sorgulamaktır.

\section{Baniler: Dönemleri, Yapıları ve Ünvanları}

Muzafferüddin İshak Bey/İshak Çelebi, kurucu Saruhan Bey (1313-1345) ve sonraki sultan İlyas Çelebi'nin (1345-1359?) ardından tahta çıkan üçüncü bey/sultandır. I. Bayezid ise Osman Gazi (1300-1324), Orhan Gazi (1324-1360) ve I. Murad'ın (1360-1389) ardından tahta çıkan dördüncü sultandır. Her iki baninin tahta bulundukları dönemler dikkate alındığında İshak Çelebi'nin Bayezid'in babası I. Murad ile yaklaşık aynı zamanlarda tahtta olduğu ve Saruhanlı Beyliğinin en 
problemsiz döneminin bu süreçte yaşandığı görülür' ${ }^{1}$. İshak Çelebi'nin başkent Manisa'ya en önemli katkısı, bünyesinde konumuzu oluşturan caminin de bulunduğu külliyesidir. İshak Çelebi/Ulu Cami Külliyesi olarak tanınan, birbirine bitişik cami-medrese-türbe-çeşme ile hamam ve mevlevihaneden oluşan bu külliye başkent Manisa'nın merkezini belirlemiştir². Kale kapısının hemen kuzeyine yerleştirilen ve merkezinde "Ulu Cami" bulunan bu külliyeyle sur dışında hem bir dini merkez, hem de bir kent merkezi/ticari merkez oluşturulmuştur ${ }^{3}$. Şehri ele geçiren Saruhan Bey ayrı tutulduğunda, Manisa kent gelişiminde kurucu olarak tek bir sultanın/İshak Çelebi'nin söz sahibi olması konumuz özelinde anlamlıdır. I. Bayezid ise kendinden önceki iki sultanın başlatmış olduğu geleneği devam ettirerek başkent Bursa' da bir külliye (zaviye-medrese-darüşşifa-türbe), bir bedesten ve bir cami inşa ettirmiştir ${ }^{4}$. Bayezid, artık sur dışına taşınmış bir kent görüntüsü çizen başkent Bursa'daki Osmanlı sultanlarının üçüncü camisi olan yapısını adeta kentin kalbine konumlandırır. Önceki iki sultan camisinin sur içerisinde olduğu düşünüldüğünde I. Bayezid'in, kent merkezini belirleyecek ve sultanı simgeleyecek "Ulu Cami” eksikliğini çok iyi gördüğünü ve adeta bu cami ile başkente imzasını attı̆̆ı rahatlıkla söylenebilir5. O halde konumuzu oluşturan iki baninin farkı I. Bayezid'in külliyesi ile önceki iki sultanın oluşturduğu bir mimari geleneği devam ettirmesine karşın cami tercihi ile fark yaratmış olması; İshak Çelebi'nin ise başkent Manisa'da anıtsal külliye, hatta yapı inşa ettiren tek sultan olmasıdır. Sözü edilen bu farklılık, başkent Manisa'nın merkezini oluşturan İshak Çelebi külliyesine Saruhanlı Beyliğinin varlığını/iddiasını simgeleyen bir yapı topluluğu olarak bakılması gerekliliğini ortaya çıkarır. Güç kazanan beylik kendisini görmek istediği yer ölçeğinde imar faaliyetine girişmiştir. C. Kafadar, Aydınoğlu beyliği üzerinden bu durumu "...daha 1312 de Osmanlıların 1330'lara kadar boy ölçüşemeyeceği derecede bol maddi kaynaklarını ve ulvi iddialarını ortaya koyan, merkezinde büyük bir cami, bir Ulu Cami'nin bulunduğu bir mimari kompleks inşa etmişti" şeklinde ifade eder (Kafadar, 2010, s. 226). İshak Çelebi'de külliyesiyle aynı "ulvi” iddiayı gütmüş olmalıdır.

Dönemin yapısı gereği var olma çabasının yaşandığı böyle bir süreçte, kişilikleri ve koşulları doğrultusunda, iddialarını ortaya koyan yöneticilerin kendilerini nasıl tanımladıkları önemlidir. Mevcut kitabeleri her iki baninin de "sultan" ününü kullandığını belgeler. İshak Çelebi, Manisa Ulu Cami kapı kitabesinde kendisini, “...büyük sultan, milletin yükünü yüklenen ikinci İskender, kafirlerin kahredicisi..." şeklinde tanıtmıştır (Acun, 1999, s. 33) ${ }^{6}$. Minber kitabesinde "...büyük sultan, milletlerin yükünü yüklenen ...", medrese kitabesinde ise yine "büyük sultan" ifadesini tercih etmiştir (Acun, 1999, s. 37, 310)7. Bu kullanımlar çok önemlidir çünkü İshak Bey'in kitabelerinde görülen "sultan", "büyük sultan" ve "han" unvanlarından yola çıkılarak beyliğin bir devlet haline geldiği kabul edilir (Eravcı \& Korkmaz, 1999, s. 43; Emecen, 2006, s. 58). Külliye yapıları bünyesinde 3

\footnotetext{
${ }^{1}$ Saruhanoğulu beyleri hakkında ayrıntılı bilgi ve Saruhanoğlu soyağacı için bkz. Uzunçarşıl1, 1988, s. 84-95.

2 Cami 768/1366-67, Medrese 780/1378-79, Mevlevihane 770/1368-69, Minber ise 778/1376-77 tarihini vermektedir (Uzunçarş1l1, 1929, s. 74-76; Acun, 1999, s. 32-66, 310-319, 350-368).

${ }^{3}$ Saruhanlı dönemi Manisa kent kurgusu için bkz. Gündüz Küskü, 2017, s. 199-218.

${ }^{4}$ I. Bayezid dönemi yapıları için bkz. Ayverdi, 1989, s. 365-530; Yıldırım Vakfiyesi için bkz. Sevim \& Öcalan, $2010: 42-$ 60.

${ }^{5}$ Sultan Orhan'ın camisinin sur içerisinde olduğu kabul edilir ancak bu yapı günümüze ulaşmamıştır. I. Murad'ın inşa ettirmiş olduğu Şehadet Cami ise Bursa iç kalesinde, sarayın hemen karşısındaki konumu ile dikkat çeker. Bu yapıların konumları hakkında tartışma için bkz. Gündüz Küskü, 2017, s. 131-136.

${ }^{6}$ Kitabenin kapı üzerindeki kısmının tamamı: "Bu güzel mabedi ve cami şerifi imar etmeye kalkan... Bu mescidin tamamlanmasinda uğraş veren büyük Sultan, milletlerin yükünü yüklenen ikinci iskenderdir. O kötülüklerin yok edicisi kafirlerin kahredicisi Allah yolunda muzaffer bir kişidir"; Kitabenin sol taraftaki kısmının tamamı: "Kulların günahlarını affeden Allah'ın inayetiyle desteklenen Saruhan Bey'in torunu, İlyas Bey'in oğlu İshak Çelebi Allah onun mülkünü daim kilsın. 768" (Acun, 1999, s. 33). Daha önce yalnızca Selçuklu sultanlarından II. Gıyaseddin Keyhüsrev'in kullandığ "Ikinci İskender" ibaresinin, Saruhanoğlulları beylerinden biri için kullanılmış olması da dikkat çekicidir. II. Gıyaseddin Keyhüsrev'in İncir Han kitabesi için bkz. Durukan, 2001, s. 100.

${ }^{7}$ Medrese kitabesinin tamamı: "Bu mübarek medresenin inşası için emretti. Mücahit ve gazilerin yardımcısl, büyük sultan, İshak Han bin İlyas bin Saruhan, Allah onun mülklerini daim kılsın...ayda 780. Bu işi Allah katında fakir ve zengin olan Hacı Emet bin Osman yaptı. Allah her ikisini de affetsin." (Acun, 1999, s. 310).
} 
farklı sanatçının çalışmış olması da Saruhanlı Beyliğinde en azından İshak Çelebi dönemi için bir saray yapım örgütlenmesinin varlığını düşündürür (Durukan, 2006, s. 149) ${ }^{8}$. İshak Bey, Saruhanoğlu beyleri içerisinde "sultan" ününü kullanan tek kişi, kurucu Saruhan Bey bir kenara birakıldığında Beyliğin başkent Manisa'da imar faaliyetinde bulunan tek yöneticisi ve yapılarıyla döneme damgasını vuran tek Saruhanlı sultanıdır. Bilindiği üzere 4 Saruhanoğlu beyine/sultanına ait 24 mimari eserden 12'si İshak Çelebi'ye aittir (Durukan, 2006, s. 149). Nitekim Saruhan Beyliğine klasik formunu kazandıran kişiliğin de İshak Bey olduğu kabul edilir (Emecen, 2006, s. 43). O halde imar faaliyetinin de işaret ettiği üzere ilk kez kullanılan "sultan" unvanı ve sanatçı örgütlenmesi de var olma çabasındaki beyliğin "varlık iddiasının" İshak Çelebi ile belgelenmiş olduğunun göstergeleridir.

Osmanlı penceresinden bakıldığında ise vakfiye ve sikkesinde "sultan" ününü kullanan ilk kişi I. Murad (1362-89) olmakla birlikte, aynı sultan günümüze ulaşan tek kitabesinde kendisini "büyük emir" olarak tanıtmıştır (Gündüz, 2009, s. 329-330). I. Murad döneminde Osmanl1, diğer beylikler üzerinde geniş bir imparatorluk kurmuş ve Ortadoğu kaynaklarında uç beyliklerinin beyi olarak tanımlanmıştır (İnalcık, 2003, s. 20-21). C. Kafadar'ın da vurguladığı üzere I. Murad'ın hükümranlığı Osmanlı Beyliği için siyasi anlamda bir dönüm noktasıdır (Kafadar, 2010, s. 238). Askeri-siyasi ve kültürel anlamda ilk devlet kurumlarının temelinin bu dönemde atılmış olması, Osmanlı Beyliğinin I. Bayezid (1389-1402) döneminde İshak Çelebi zamanındaki Saruhanoğullarına göre çok daha gelişmiş bir örgütlenme içerisinde olduğunu belgeler. Devlet örgütlenmesi ve düzeni imar faaliyetleri üzerinden de okunabilir. Osmanlı Beyliği döneminde 6 bey/sultan 172 yapı inşa ettirmiştir. Yapı yoğunluğu ve çeşitliliğiyle ilk sırayı 46 yapı inşa ettiren I. Bayezid (1389-1402)

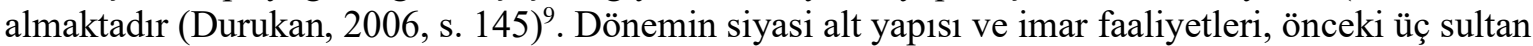
döneminde "varlık iddiasını" ortaya koymuş bir beyliğin sultanı olarak I. Bayezid'in eserlerinde bireysel anlamda da bir güç vurgusunun öne çıktığını düşündürür. Bu nedenle I. Bayezid'in Bergama'daki Cami (1398-99) kitabesinde “...büyük sultanlar sultanı, Arap ve Acem ülkelerinin emîri, mücahid ve gazilerin yardımcısı..." olarak anıldığı sıfatlarına ek olarak, Edirne İmareti’ndeki (1400) “...Allah'ın gölgesi, milletin yardımcısı, yüce sultan..." şeklindeki sıfatları hiç şaşırtıcı değildir ${ }^{10}$. Üstelik bu sıfatlar arasındaki "büyük sultanlar sultanı" ve "Arap ve Acem ülkelerinin emîri" şeklindeki, Osmanlı sultanları arasında ilk kez karşılaşılaşılan bu iki ibare, adeta I. Bayezid'in, bulunduğu bölgenin/beyliğinin dışına taşan gücünü ilan ettiğinin de belgesidir ${ }^{11}$.

Araştırmacı Kafadar, Osmanlı Beyliği'nin daha başlangıcından itibaren Bizans kadar Müslüman-Türk komşularıyla (diğer beyliklerle) da rekabet halinde olmalarını vurgulayarak ilk Osmanlı sultanlarının kullandıkları "dinin savunucusu" sıfatını anlamlandırmaktadır (Kafadar, 2010, s. 123). Bu noktada bizi ilgilendiren kuruldukları ilk andan itibaren zaman zaman ittifaklar kurmuş olsalar da bu beyliklerin birbirleri ile sürekli bir rekabet halinde olmalarıdır ${ }^{12}$. Bu rekabet dünyas1 imar faaliyetlerinin yanı sıra sultanların sanatçı seçimlerini de etkilemiştir. Bilindiği üzere özellikle Ortaçağ Anadolu'sunda devletlerarası sanatçı geliş gidişleri sanatçıların bağımsız iradelerinin yanı

\footnotetext{
${ }^{8}$ Manisa Ulu Cami minberinde Antepli Hacı Mehmed ile birlikte Nakkaş Yusuf adı da okunmaktadır. Bununla birlikte, Külliye ve Mevlevihane'de, Hacı Emet isimli bir sanatçının çalışmış olduğu da bilinir (Acun, 1999, s. 32-66, 310-319, 350368).

${ }^{9}$ Osmanlı ve tüm diğer beyliklerin yapıları hakkında sayısal değerlendirmeler için bkz. Durukan, 2006, s. 137-171.

${ }^{10}$ Bergama Ulu Cami kitabesinin tamamı: "Bu şerefli mescid (ve) güzel camiyi, büyük sultanlar sultanı, Arap ve Acem ülkelerinin emîri, mücahid ve gazilerin yardımcısı Murad Han oğlu Bâyezid Han-Allah mülkünü devamlı kılsın 801 yılında yaptırmıştır" (Tüfekçioğlu, 2001, s. 86-87). Edirne Yıldırım İmareti kitabesinin tamamı: " Orhan oğlu, Murad oğlu, Allah'ın (yeryüzündeki) gölgesi, milletin yardımcısı, yüce sultan Bâyezid, âlimler, fakirler ve diğer kimseler için vakfedilmek üzere imar edilmiş olarak devam edecek (bu imaretin yapılmasını) hilâlî 802 yılında emretti" (Tüfekçioğlu, 2001, s. 92-93).

${ }^{11}$ Bilindiği üzere, Anadolu Selçukluların'da da bu tarz siyasal anlamda gücü tanımlayan sıfatlar ilk kullanıldıklarında kişisel başarıyı işaret etmekle birlikte süreç içerisinde kalıplaşarak sonraki sultanlar tarafından da kullanılmışlardır (Gündüz Küskü, 2014, s.57-58).

${ }^{12} \mathrm{Bu}$ beylikler arasındaki inişli-çıkışlı ilişkiler konusunda ayrıntılı bilgi için bkz. Kafadar, 2010, s. 203-261.
} 
sıra banilerin istekleri doğrultusunda da gerçekleşmiştir ${ }^{13}$. Zaman zaman ise banilerin sanatçı tercihleri güç gösterisi ve kendini ifade etme aracı olarak değerlendirilmiştir (Özbek, 2002, s. 351; Gündüz, 2011, s. 164). Bu nedenle güçleri ve başta bulundukları dönemlerin güç dengeleri farklı olsa da I. Bayezid'in başkent Bursa'nın merkezinde yer alan camisinin minberini, İshak Çelebi'nin yanı sıra Saruhanoğlu Beyliği'ni de simgeleyen bir yapı olan Manisa Ulu Cami minberinden 23 yıl sonra aynı sanatçıya yaptırmış olması anlamlıdır.

\section{Minberler: Manisa Ulu Cami Minberi (1376)}

Abanoz ağacından yapılmış olan Manisa Ulu Cami'nin 1376 tarihini veren minberi kündekari tekniğinin beylikler dönemine ait en önemli örneklerinden biridir (Resim 1). Minberin nervürlü kapı kemerinin hemen üzerinde, ince bir pano içerisinde inşa kitabesi bulunur (Resim 2) ${ }^{14}$. Minber korkuluğunun her iki tarafinın alt orta kısmında ise "Amele el-Hāc Muhammed bin 'AbdālAziz ibn el-Dāki El-Ayıntabî̀" şeklinde usta kitabesi yer alır (Acun, 1999, s. 37) (Resim 3). Minberdeki diğer sanatçı kitabeleri minber kapı kanatlarının alt kısımlarındaki dikdörtgen panolar üzerindedir. Sol kanattaki kitabe tekrardan "Amele el-Hāc Muhammed bin 'Abdāl-Aziz ibn el-Dāki" ismini verirken sağ kanattaki "Ketebe hattahu ve reseme nakkaşahu Fakih bin Yusuf" isimli bir diğer sanatçı adını vermektedir (Acun, 1999, s. 37; Oral, 1962, s. 67-68, Sönmez, 1995, s. 40, 352) (Resim 5). Mevcut kitabeler, minber bezeme tasarımının "Fakih bin Yusuf" isimli bir sanatçı tarafından yapıldığını, Bursa Ulu Cami minberinde de imzası bulunan el-Dāki'nin ise bu minberde ahşabı işleyen sanatçı olarak karşımıza çıktığını belgeler. Ancak bu noktada dikkat çeken el-Dāki’nin minberin üç ayrı noktasına ismini yazmış olmasıdır ki bunun da bilinçli bir tasarım/tercih olduğu düşünülür (Bayrakal, 2008, s. 71). Ahşap sanatçısı olarak kendi ismini ön plana çıkarmıştır.

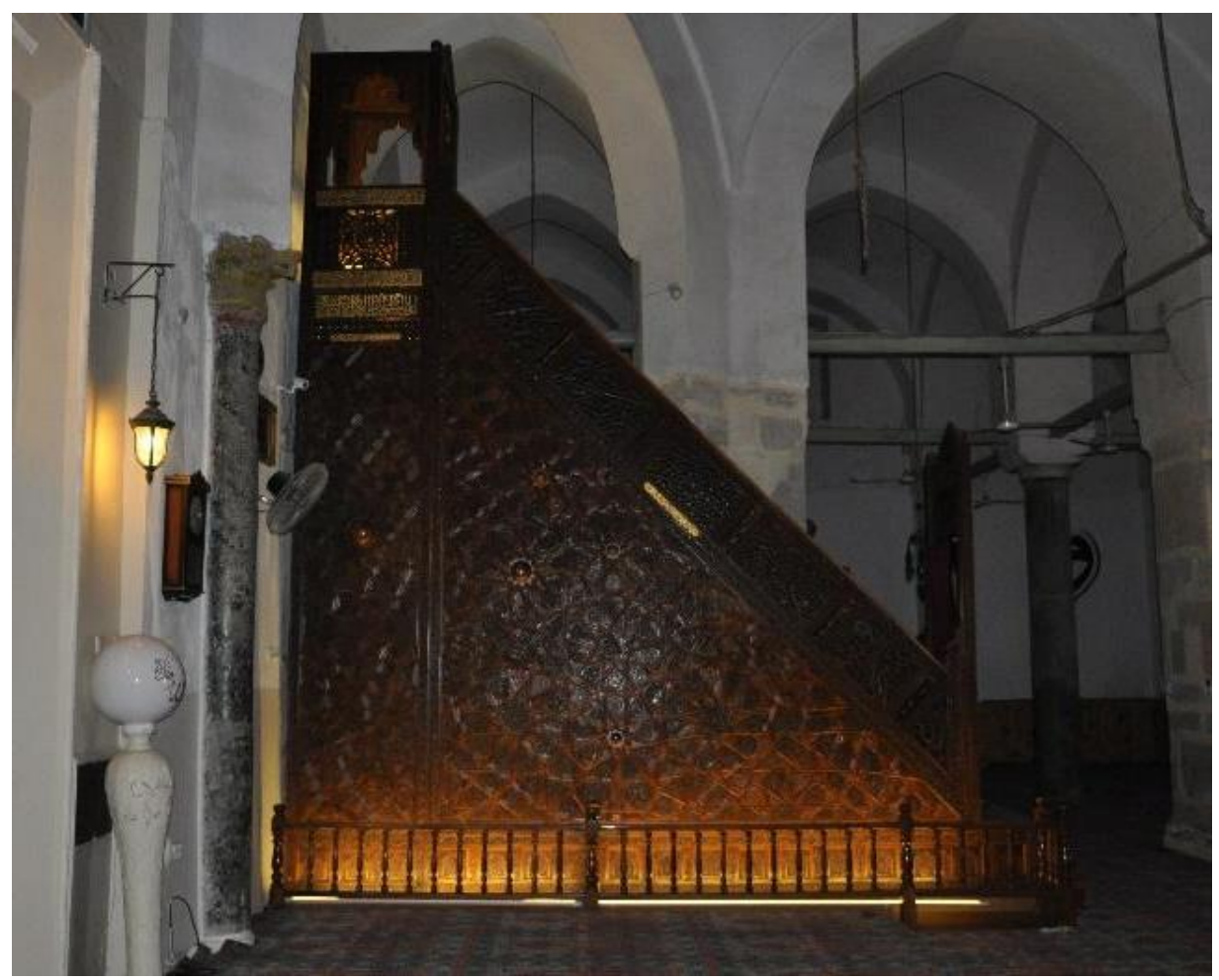

Resim 1: Manisa Ulu Cami Minberi ${ }^{15}$.

\footnotetext{
${ }^{13}$ Dönemin sanatçı geliş-gidişleri hakkında daha geniş bilgi için bkz. Gündüz Küskü, 2014, s. 90-113.

${ }^{14}$ Minber kitabesi, "Bu mübarek minberin yapılmasını büyük sultan, milletlerin yükünü yüklenen, İlyas oğlu İshak Çelebi emretti. Allah onun zaferlerini aziz kilsin. 778." (Acun, 1999, s. 37).

${ }^{15}$ Kaynak gösterilmeyen fotoğraflar yazarın arşivinden alınmıştır.
} 


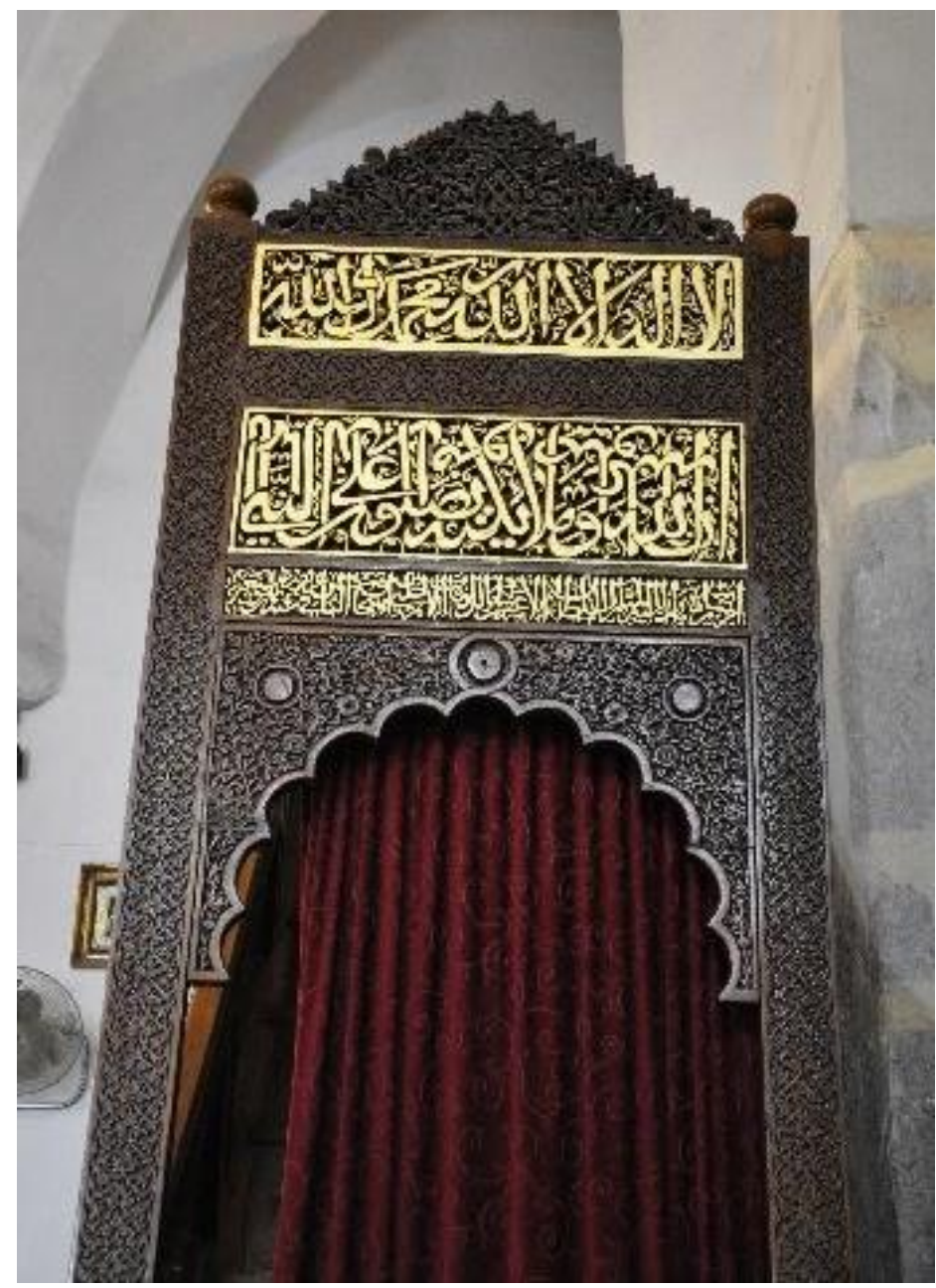

Resim 2: Manisa Ulu Cami Minberi, Kapı Alınlı̆̆1.

Minberin külah kısmı günümüze ulaşmamıştır. Minber kemerli tasarıma sahip bir pabuçluk üzerine oturur (Resim 1). Yuvarlak yüzeyli oyma tekniğinin görüldüğü papuçluk, kemer yüzeylerinde rumilerin palmete çerçeve oluşturduğu bir kompozisyon, kemer aralarındaki dikey şeritlerde ise kıvrıkdaldan çıkan rumi kompozisyonu ile hareketlendirilmiştir. Papuçluğun üzerinde kündekari tekniğindeki aynalık yükselir. $\mathrm{Bu}$ bölümündeki temel bezeme büyük olanlarının merkezlerine çeşitli büyüklükte kabaraların/yarımkürelerin yerleştirildiği çok kollu yıldız kompozisyonu şeklindedir (Resim 1, 4). Taht altı kısmında da aynı geometrik bezeme devam eder. Geometrik bezemenin yüzeyini oluşturan künde parçalarının üzeri ise yuvarlak yüzeyli oyma tekniği ile kıvrık dal, palmet ve rumilerden oluşan bitkisel bezeme yer alır (Resim 4). Oldukça ince bir işçilikle uygulanmış olan bitkisel bezeme, aynalıkları çevreleyen ince şerit ile kafes tekniğindeki korkuluk levhalarını alt kısmı boyunca uzanan bir diğer şeritte kıvrık dal-rumi ikilisi şeklinde devam eder (Resim 3). Taht altı kısmını çevreleyen ince şeritte ise bu kompozisyona palmetler dahil edilmiştir. Tüm bu kompozisyonlardaki rumilerin yüzeyi yivlerle hareketlendirilmiştir. Ancak korkulukları oluşturan, kafes tekniğindeki beş dikdörtgen panonun (iki köşedeki yarımlar hariç) arasındaki dikey şeritlerin bitkisel bezemeleri biraz farklıdır. Düz yüzeyli oymanın görüldüğü bu kısımlarda motifler de tam olarak algılanamamaktadır (Resim 3). Korkulukların üst kısmı boyunca uzanan, ardarda palmet-lotus motiflerinin tekrar edildiği şeritte ise lotusların gövdesi geçme şeklinde yürek motiflerine dönüşmüştür. 


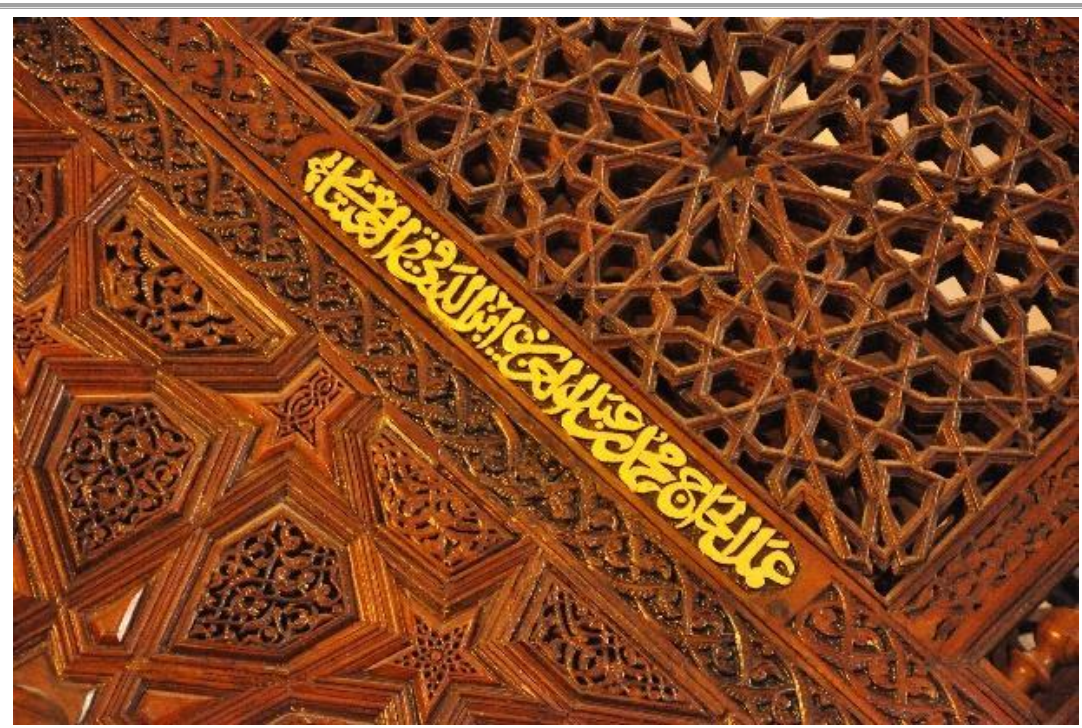

Resim 3: Manisa Ulu Cami Minberi, Sanatçı Kitabesi.

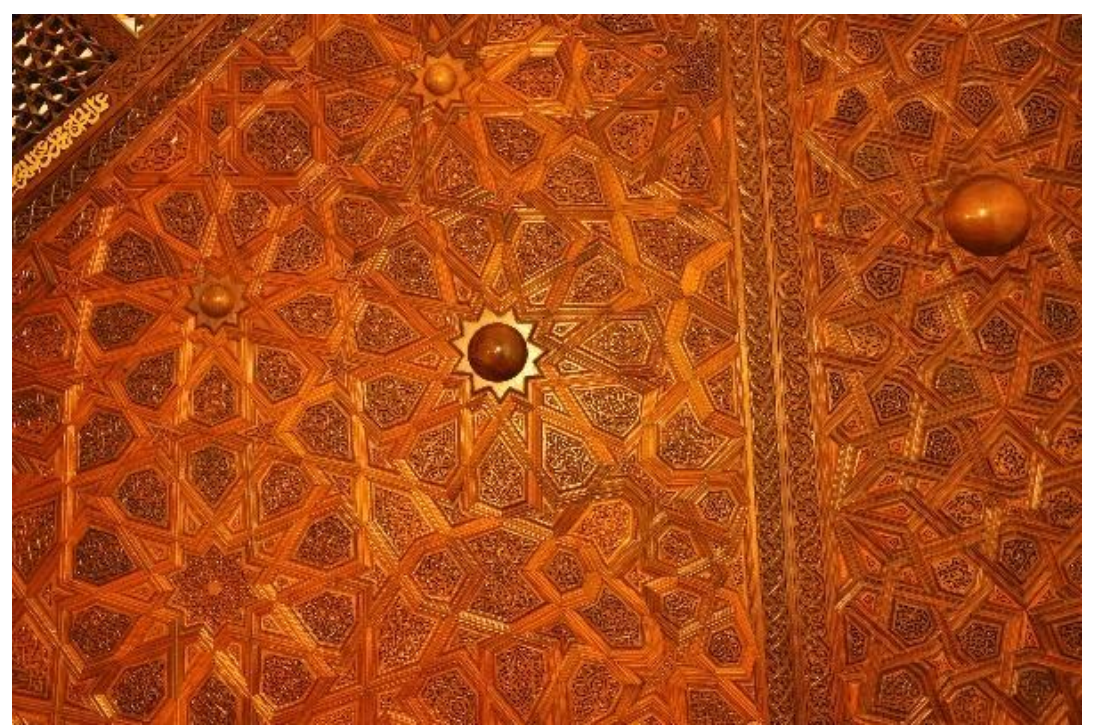

Resim 4: Manisa Ulu Cami Minberi, Aynalık Ayrıntı.

Minberin tekniği ve üslubu ile fark yaratan kısmı kapı bölümüdür. Uzunlamasına bir şerit şeklinde olan kapı söveleri birbirine geçen kıvrık dallardan çıkan rumilerin palmetlere çerçeve oluşturduğu bir düzenleme yansıtır (Resim 2). Tepede bir düğüm ile sonlanan on bir dilimli kapı kemerinin köşelikleri yine bitkisel bezemelidir. Ancak bu bölümün bezemesi üslup ve motif tercihi açısından yukarıda ele alınan tüm minber bezeme üslubundan ayrılır. Ondördüncü yüzyıl ile birlikte ortaya çıkan çeşitli yaprak ve çiçek desenlerinin bulunduğu kompozisyonların ortasına birer bezemesiz kabara yerleştirilmiştir (Resim 2). Dilimli kapı kemerinin üst kısmında ise genişlikleri farklı üç yazı bezemeli pano yer alır. Bunlardan en altta ve en dar alanı kaplayan bani kitabesidir. Diğer iki kitabeden üstteki Kelime-i Tevhid, aradaki en geniş olanında ise bir ayet yer alır (Resim 2) ${ }^{16}$. Bu kısmın üzerinde üçgen şeklinde tasarlanmış rumi, palmet ve kıvrık dallardan oluşan bitkisel bezemeli taç kısmı bulunur (Resim 2). Delik işi/ajur tekniğindeki bu kısım eski bir fotoğraftan anlaşılacağı üzere özgününde tepe noktasında bir palmet ile son bulmaktadır.

${ }^{16}$ Sure 33, Ayet 56 yazilıdır. Anlamı: “Allah ve Melekleri Hazret-i Muhammed'e dua ederler. Ey mü'minler siz de onun üzerine salât ve selâm getiriniz” (Oral, 1962, s. 40, 66). 
Kapı bölümünün en önemli parçaları kapı kanatlarıdır. Kanatlar bezemeleri açısından tek parçaymış gibi tasarlanmışlardır (Resim 5). Kapalı olduklarında üst kısımda yedi dilimli kemerli bir düzenleme yansıtan kanatlarının her biri iki yandan bitkisel bezemeli birer şerit ile sınırlandırılmıştır. $\mathrm{Bu}$ iki şerit ve dilimli kemerin yüzeyi tıpkı yukarıda işaret edilen kemer köşeliklerinde olduğu gibi farklı yaprak ve çiçek desenlerinin bulunduğu bitkisel bezeme tasarımına sahiptir (Resim 5). Buradaki motiflerin en yakın benzerleri mermer malzeme ile Milas Firuz Bey Zaviyesi'nde (1396) karşımıza çıkar. Arada kalan kısım ise farklı boyutta altışar dikdörtgen panolara ayrılmıştır. Ortadaki büyük boyutlu dikdörtgen pano üstten ilki makîli, ikincisi sülüs yazı bezemeli iki pano, alttan ise iki sülüs yazı bezemeli pano arasına yerleştirilen makîli yazılı bir pano ile sınırlandırılmıştır (Resim 5). Daha önce de ifade edildiği üzere en alt panolar sanatçı isimlerini verirken diğerlerinde bir hadis yer alır ${ }^{17}$. Kapı kanatlarının en önemli bölümü 12 kollu yıldız kompozisyonunun bulunduğu geometrik bezemeli ortadaki en geniş panolardır. Bu panoları farklı kılan kakma işçiliğe sahip bezemeleridir. Minberin yalnız bu bölümünde bulunan kakmalar, kompozisyonu oluşturan yıldızların merkezi ile yıldız kolları arasında oluşan düzgün olmayan altıgen bölümler ile beş ve üç kollu/dilimli yıldızların yüzeyine uygulanmıştır. Yıldız merkezleri ve altıgenlerin yüzeylerinde daha ince bir işçilikle uygulanmış olan kakmalar diğer kısımlarda çok daha büyük parçalar şeklinde kakılmıştır (Resim 5). Minberin, dört yönden dilimli kemerli tasarıma sahip olan taht kısmı ise kafes tekniğindeki korkulukları hariç tümüyle yenilenmiştir (Resim 1).

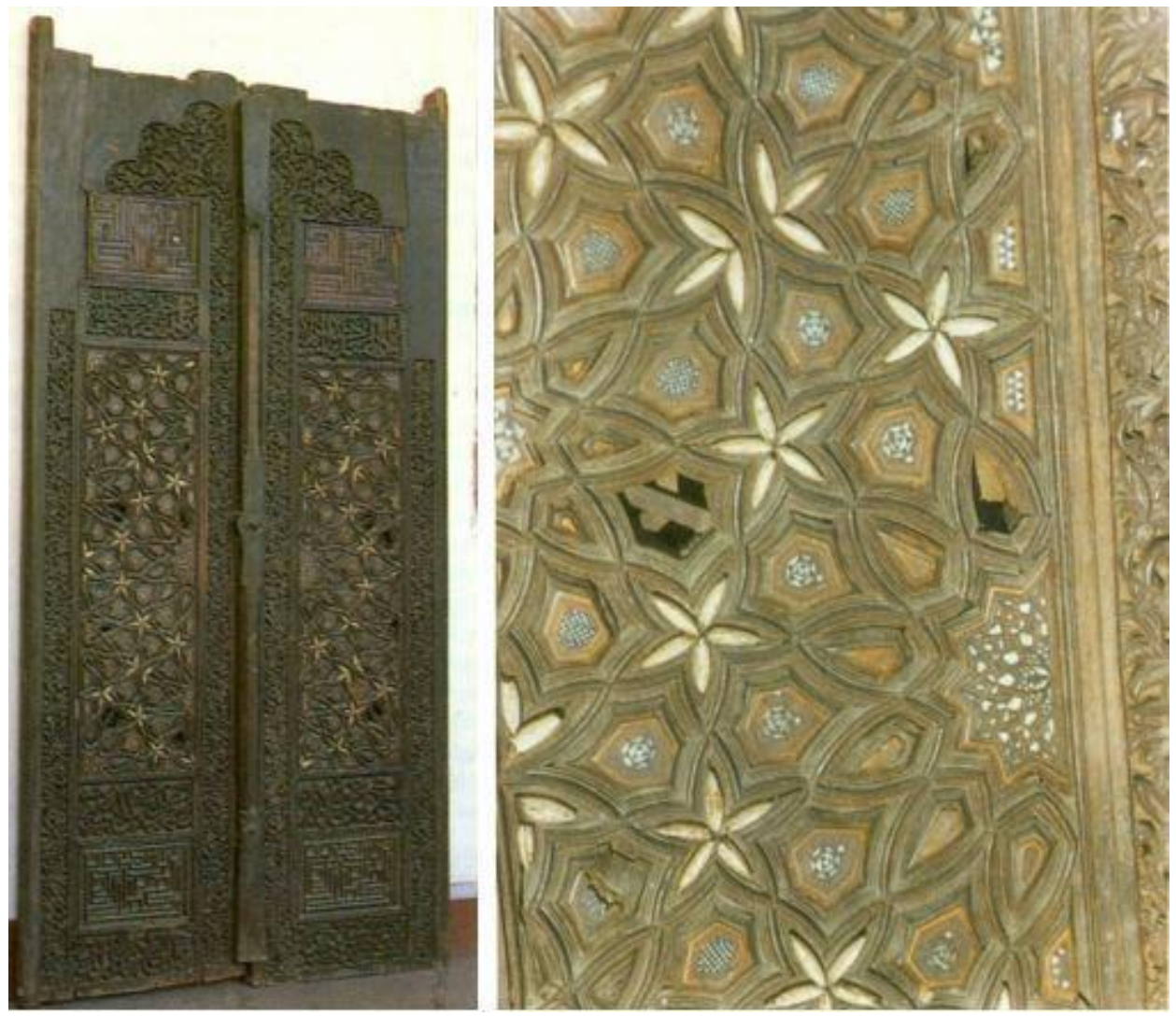

Resim 5: Manisa Ulu Cami Minberi, Kapı Kanatları (Acun, 1999, s. 62, 64).

Görüldüğü üzere, teknik, üslup, ölçek ve kurgu açısından büyük ölçüde Anadolu Selçuklu geleneğini devam ettirmiş olan bu minberin, kapı kanatlarındaki kakma tekniği ile kapı bölümündeki farklı çiçek ve yaprak motifleri tipik 14. yy. beylikler dönemi özellikleri sergiler. Kakma tekniğinin beylikler dönemi öncülleri Eretna Beyliği yöneticilerine ait olan Niğde Sungur Bey Cami (1335) ile

${ }^{17}$ Buradaki yazılar için bkz. Oral, 1962, s. 66-68; Acun, 1999, s. 37. 
Ürgüp Damsaköy Taşkınpaşa Cami (1350’ler) minberleridir ${ }^{18}$. Ancak Manisa Ulu Cami minberi çok daha anitsal bir uygulama olarak bu örneklerden ayrılır. Bu nedenle Manisa Ulu Cami minberinin de banisinin kimliği ve iddiasını direkt olarak ortaya koyan bir minber olduğu rahatlıkla söylenebilir.

\section{Minberler: Bursa Ulu Cami Minberi (1399)}

Bursa Ulu Cami minberi ise aynı sanatçının bir sultan için inşa etmiş olduğu ikinci eseridir. Ceviz ağacından kündekari tekniği ile yapılmış olan ve kitabesi 1399 tarihini veren bu minber döneminin en anıtsal örneğidir (Resim 6) ${ }^{19}$. Minberin kapısı üzerinde yer alan dikdörtgen panoda I. Bayezid'in adını veren inşa kitabesi bulunur (Resim 7, 8) ${ }^{20}$. Minberin batı korkuluk panolarını birbirinden ayıran dikey şeritlerden biri üzerinde ise "(Bu minberi) Dakkî oğlu Abdülaziz oğlu Hacı Muhammed yaptı" şeklinde ifade edilen sanatçı kitabesi yer alır (Tüfekçioğlu, 2001, s. 90) (Resim 9) ${ }^{21}$. İlginçtir ki Manisa minberinde üç farklı konuma (simetrik olarak korkulukların alt orta kısımları ile kapı kanadının birinde) kitabesini yerleştirmiş olan Hacı Muhammed, bu minberinde adını yalnız bir kez yazmıştır/yazabilmiştir.

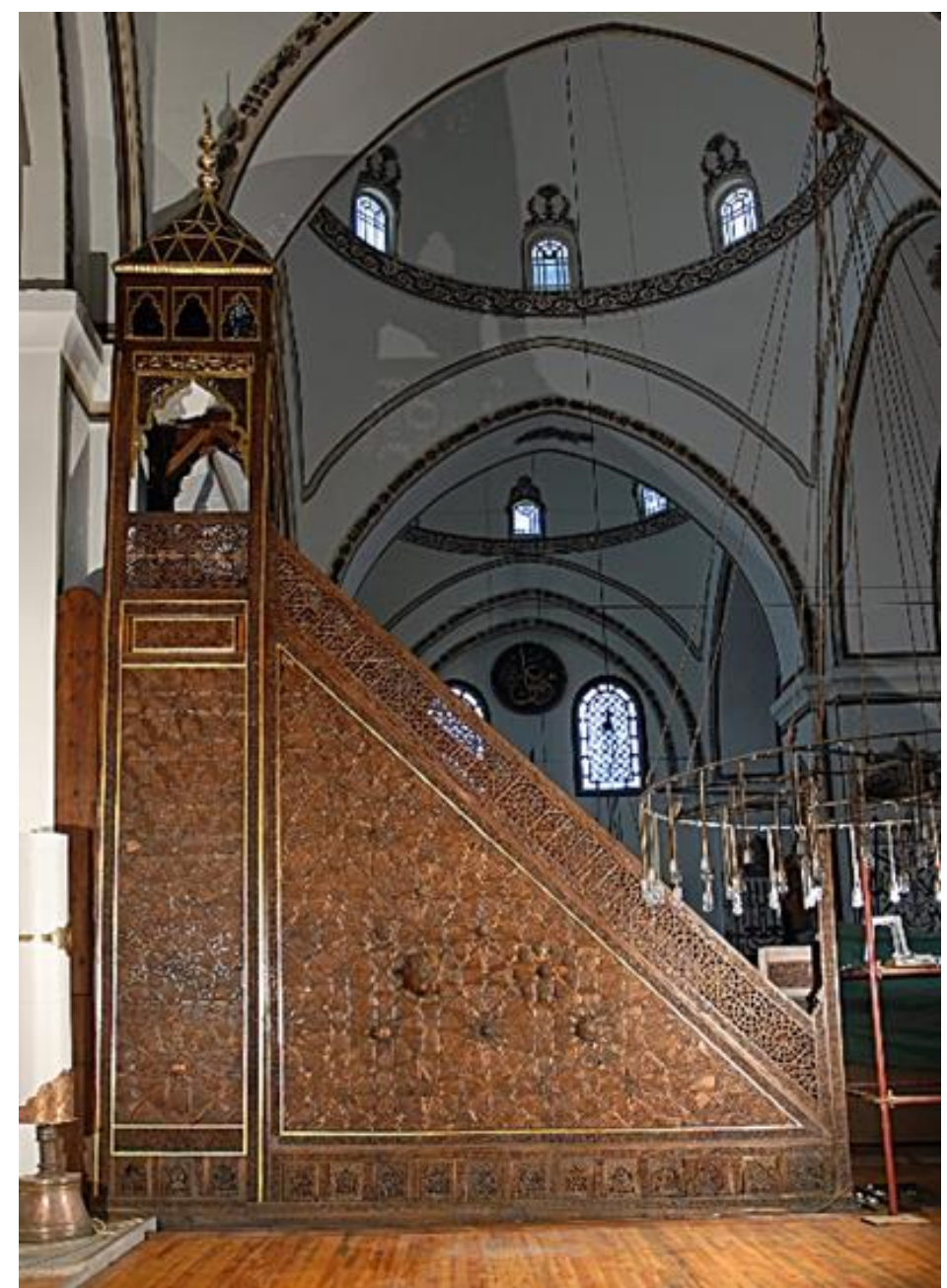

Resim 6: Bursa Ulu Cami Minberi (İrteş, 2009, s. 152).

\footnotetext{
${ }^{18}$ Günümüzde Sungur Niğde Dışarı Cami’sinde bulunmaktadır.

${ }^{19} 141$ x596 cm. boyutları ile Selçuklu ve Beylikler dönemi minberlerinin en büyüğüdür (Bayrakal, 2008, s. 61).

20 “Murad Han oğlu Yüce Sultan Bayezid'in emriyle (Bu minber) 802 yılında yapıldı" (Oral, 1962, s. 71; Tüfekçioğlu, 2001, s. 90).

${ }^{21}$ Sanatçı kitabesi ve Dakkî kelimesi tartışmaları için bkz. Tüfekçioğlu, 2001, s. 91; Bayrakal, 2008, s. 69-70.
} 
Tüm anıtsallığı ile günümüze ulaşan minberin yalnız külah kısmının üst bölümü ve bazı künde parçaları yenilenmiştir. Minber, Manisa Ulu Cami minberinde de olduğu gibi dilimli kemerli bir pabuçluk üzerine oturur (Resim 6). Ancak bu minberde farklı olarak kemer yüzey bezemesinde delik işi tekniği görülür. Rumilerin palmete çerçeve oluşturduğu bitkisel kompozisyon ise aynı kalmıştır. Kemerlerin çevresine oyma olarak daha natüralist üslupta farklı çiçek motifleri uygulanmıştır. $\mathrm{Bu}$ natüralist çiçek motifleri kemerli panoların arasına yerleştirilmiş olan dikey şeritlerde de kullanılmıştır. Minberin pabuçluk bölümünde karşımıza çıkan bu daha natüralist üsluptaki çiçek ve yaprak motifleri Daki'nin her iki minberde de çok kısıtlı bir alanda uygulamış olduğu 14. yy. özelliği yansıtan bitkisel kompozisyonlardır. Ancak Manisa Ulu Cami minberinde bu kompozisyonu, kapı kemer köşelikleri gibi çok daha göz önünde olan bir bölümde tercih edildiği unutulmamalıdır. Aslında bu farklılık Manisa Ulu Cami minberinde tasarımları yapan Fakih bin Yusuf isimli bir diğer sanatçının varlığı ile ilişkilendirilebilir.

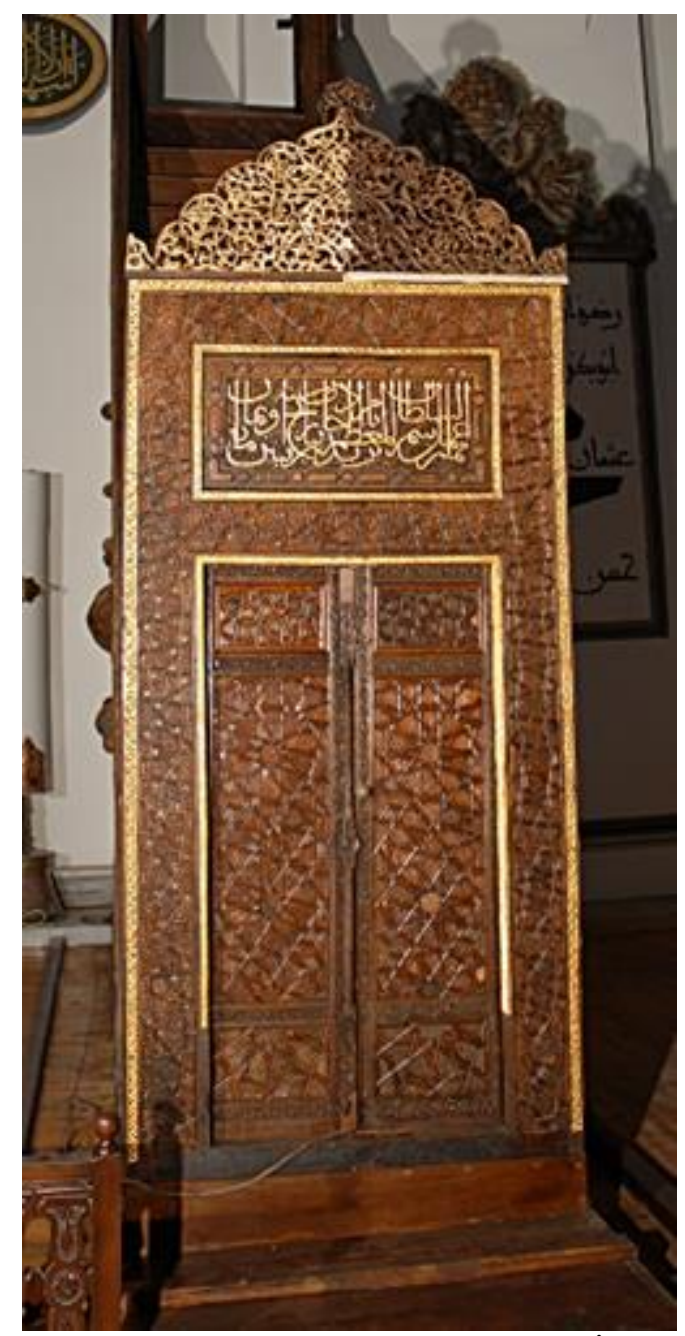

Resim 7: Bursa Ulu Cami Minberi, Kap1 Bölümü (İrteş, 2009, s. 158). 


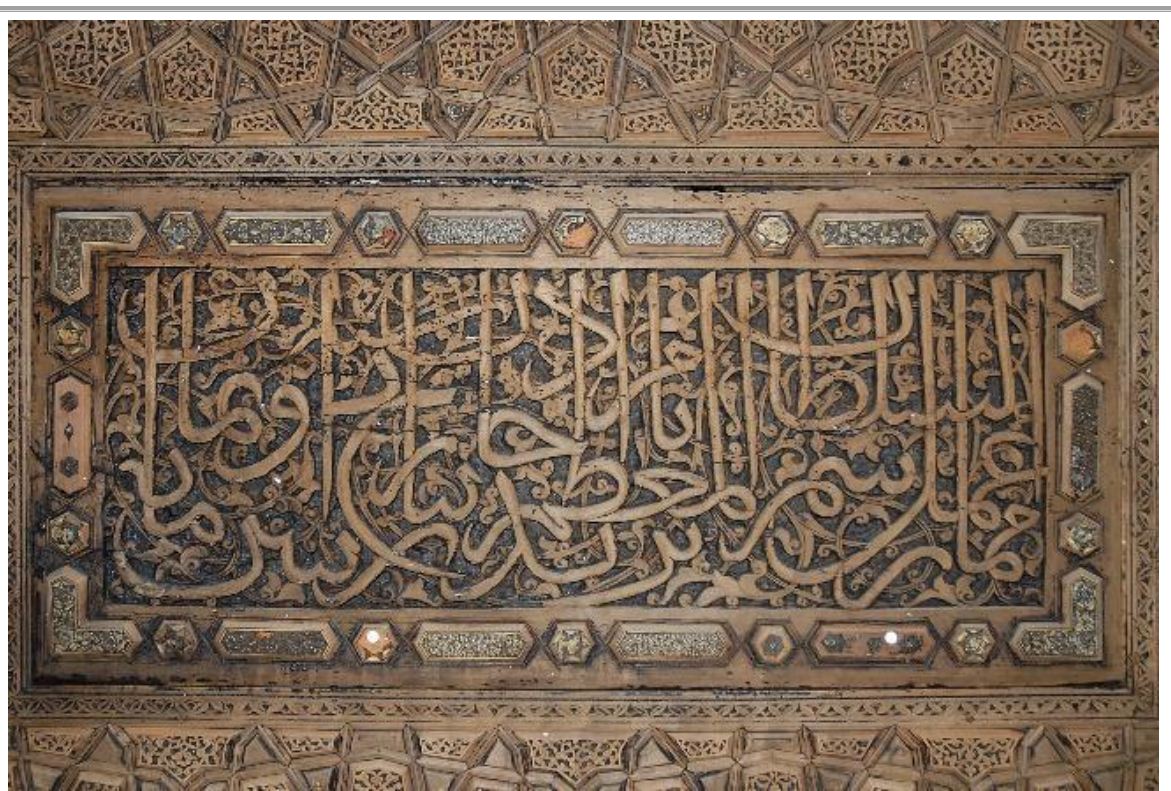

Resim 8: Bursa Ulu Cami Minberi, Bani Kitabesi (İrteş, 2009, s. 58).

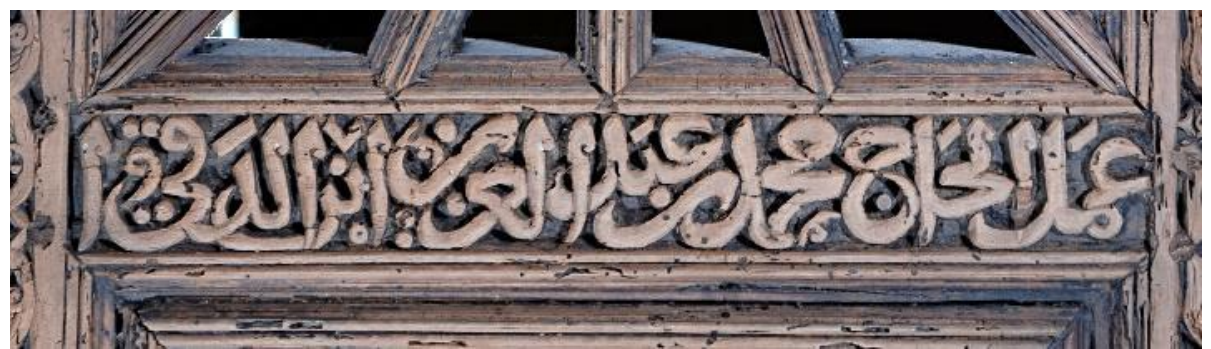

Resim 9: Bursa Ulu Cami Minberi, Sanatçı Kitabesi (İrteş, 2009, s. 156).

Kündekari tekniğindeki aynalık bölümünün temel bezemesi büyük olanlarının merkezlerine çeşitli boyutlarda kabaraların yerleştirildiği kırık çizgilerin birbiri içerisine geçirilmesiyle biçimlenen çok kollu yıldızlardır (Resim 6) ${ }^{22}$. Ancak bu minberdeki en önemli özellik her iki aynalıkta tercih edilen geometrik kompozisyonların farklı olmasıdı2 ${ }^{23}$. Yıldızların kolları arasında kalan künde yüzeylerinde ise, yuvarlak yüzeyli oyma tekniği ve çok ince bir işçilikle uygulanmış kıvrık dal, palmet ve rumilerden oluşan bitkisel kompozisyonlar görülür. Büyük yıldızların kollarını oluşturan künde parçalarındaki bitkisel kompozisyonların arasına geleneksel üsluptan ayrılan yer yer küçük çiçek motifleri yerleştirilmiştir. Fakat bu iki minber arasındaki en önemli farklılık bu değildir. Bursa Ulu Cami minberinde, batı yan aynalığında bulunan kabaraların yüzeyleri ile kabaraları çevreleyen künde parçaları ve aralardaki beş kollu yıldızların yüzeylerinde çok ince bir işçilikle kakma tekniğiyle işlenmiş geometrik bezemelerin varlığı dikkat çekicidir (Resim 10-11) ${ }^{24}$.

\footnotetext{
${ }^{22}$ Tüm kompozisyonlarının ayrıntılı tanıtımı için bkz. Bayrakal, 2008, s. 60-72; İrteş, 2009, s. 145-163.

${ }^{23}$ Minberin iki yan aynalığının farklı kompozisyona sahip olduğu diğer minber örnekleri Çorum Ulu Cami (1306) ile Çorum Hamid Cami'sindeki (130?) minberlerdir (Karamağaralı, 1964, s. 127).

${ }^{24}$ H. Karamağaralı 1955 yılında kismen gördüğ̈̈ parçalardan bu bölümlerde "kakma" tekniğinin bulunduğuna işaret eder (Karamağaralı, 1955, s. 63-66), S. Bayrakal ise temizlenmiş birkaç parçadan yola çıkarak buradaki tekniğin "tarşi" olduğunu özellikle vurgulamaktadır. Minberin 2006-2009 yılları arasındaki restorasyonunda tüm yüzeyleri temizleyerek bütün parçaları ortaya çıkaran S. İrteş ise bu tekniği "hatemkari" olarak tanımlar (İrteş, 2009, s. 153). İslam Ansiklopedisi'nde "Kakma", "Maden, ahşap, fildişi, bağa, mermer gibi malzeme üzerine istenen motife göre açılan yuvalara farkl renkte aynı cinsten veya farkl cinsten, genellikle daha klymetli malzemeden kesilmiş parçaların yerleştirilmesiyle yapılan bir süsleme türüdür.” şeklinde tanımlanmıştır (Bozkurt, 2001, s. 216-217). Bu tekniğin Arapça karşıllkları ise "tarsi", "tekfît" ve "tet‘îm" dir. Osmanlılar ahşap kakmacıllı̆̆ına "hâtemkâr̂̂" demişlerdir (Bozkurt, 2001, s. 216-217). Metinde, temelde hepsi aynı anlamı karşılayan bu kelimelerden "kakma" tanımı tercih edilmiştir.
} 


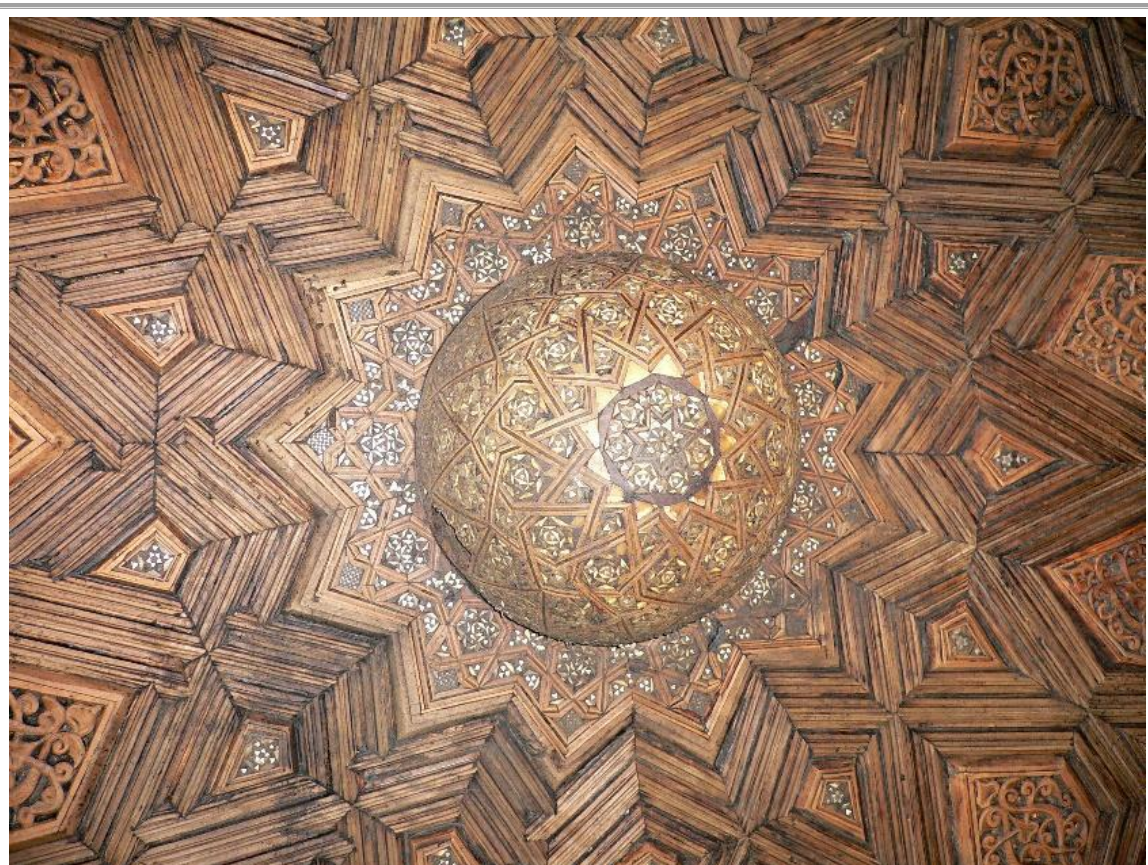

Resim 10: Bursa Ulu Cami Minberi, Batı Aynalığındaki Kakmalardan Ayrıntı (İrteş, 2009, s. 153).

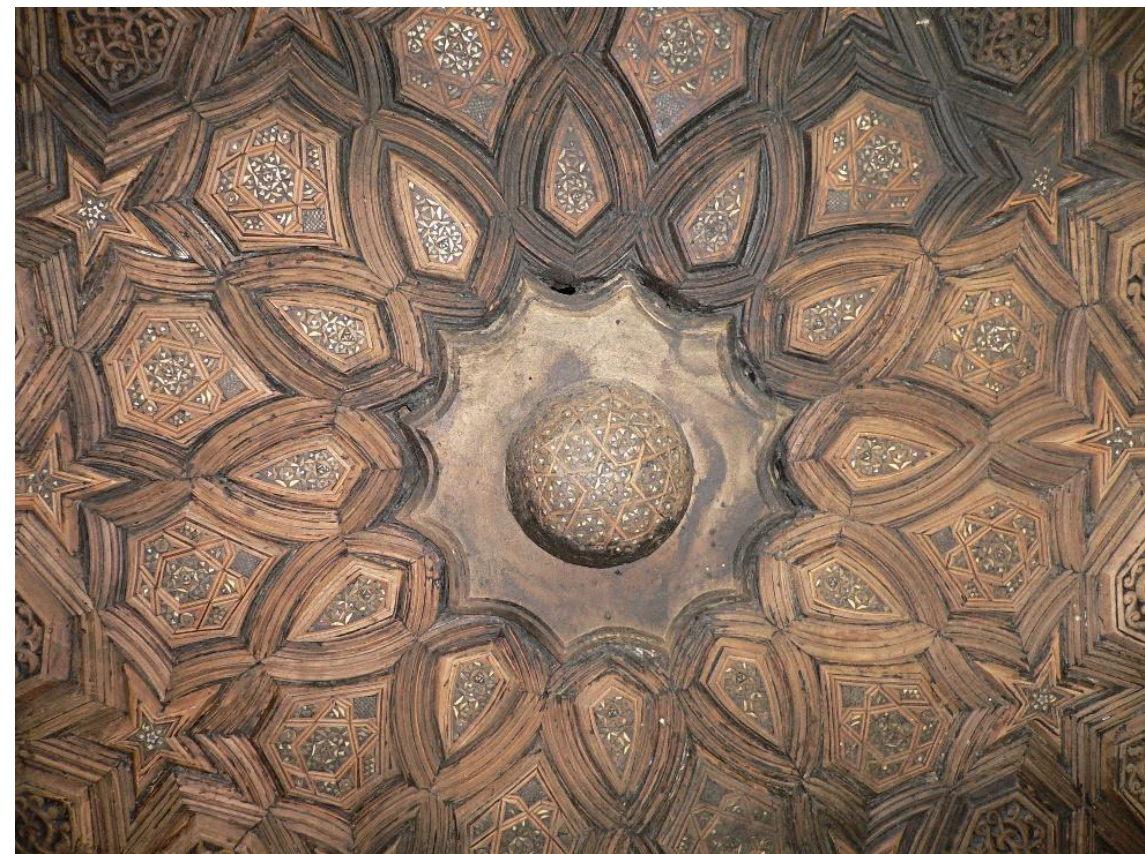

Resim 11: Bursa Ulu Cami Minberi, Batı Aynalığındaki Kakmalardan Ayrıntı (İrteş, 2009, s. 153).

Minberin taht altı bölümünde kündekari tekniğinin yanı sıra benzer bir geometrik kompozisyon da mevcuttur. Bu bölümde de hepsi günümüze ulaşamamış olmakla birlikte bazı yıldızların merkezine kabaralar yerleştirilmiş̧tir. Doğu taht altı panosunda, ortadaki yıldızın merkezinde yer alan kabara ile alt bölümdeki bazı yıldızlar, yıldız kolları ve çokgen yüzeylerinde yine çok ince bir işçilikle uygulanmış olan kakma tekniğinde bezemeler görülür (Resim 12). Batı taht altı panosunda ise orta kısımdaki yıldız ağlarını oluşturan çıtaların yüzeyi küçük dikdörtgen panolar olarak düşünülmüş ve tüm bu yüzeylerde yine çok ince bir işçilikle kakma tekniği uygulanmıştır (Resim 13). Çıtaların yüzeyi dışında bu bölümdeki yıldız kolları arasında oluşan beş kollu yıldızların yüzeyleri de kakmalarla hareketlendirilmiştir. Ayrıca, bu bölümdeki yenilenmiş 
olduğu anlaşılan bazı parçalar minberin küçük çapta bir onarım geçirmiş olduğuna işaret eder (Resim $13)$.

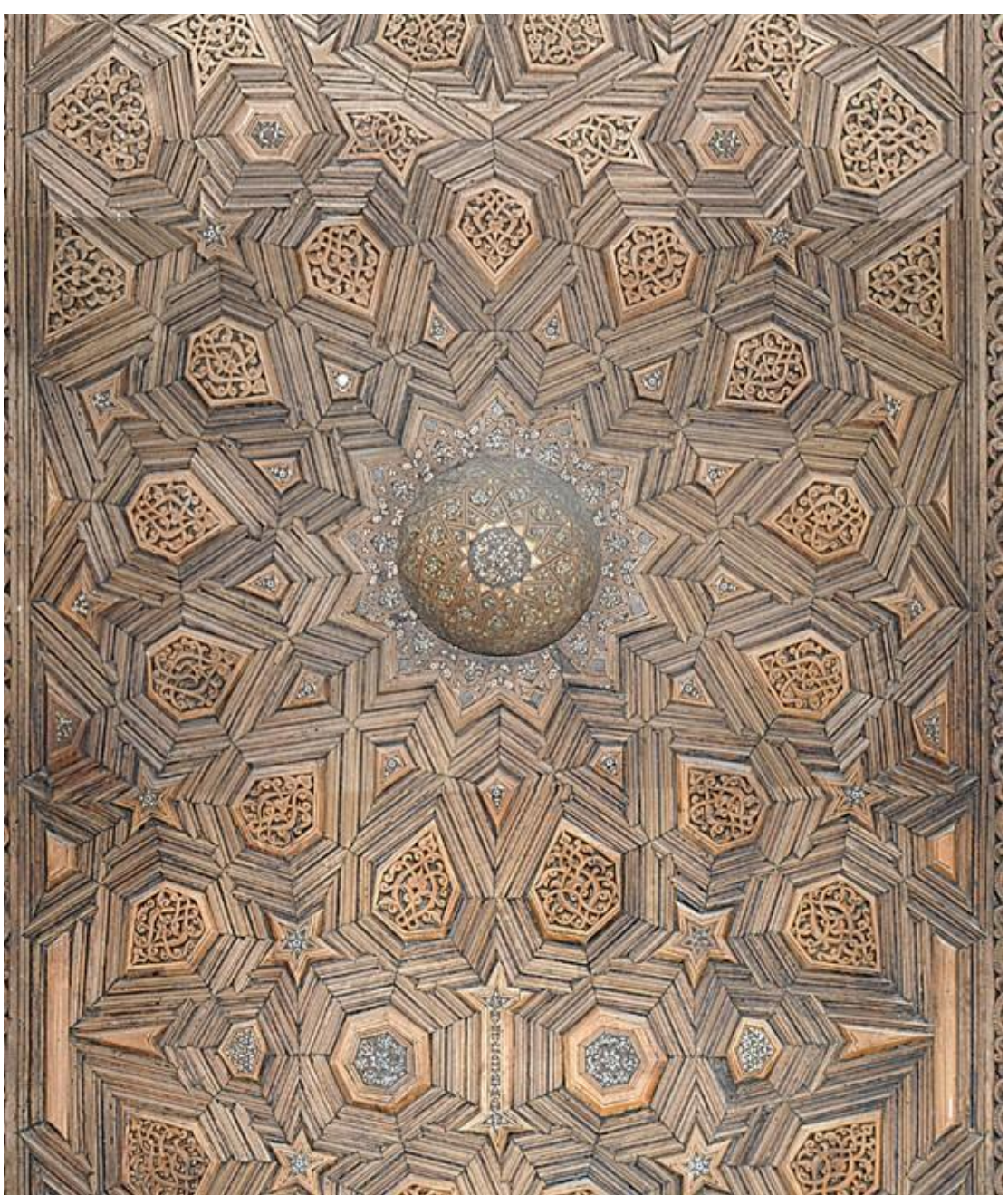

Resim 12: Bursa Ulu Cami Minberi, Doğu Taht Altı Bölümü Ayrıntı (İrteş, 2009, s. 156). 


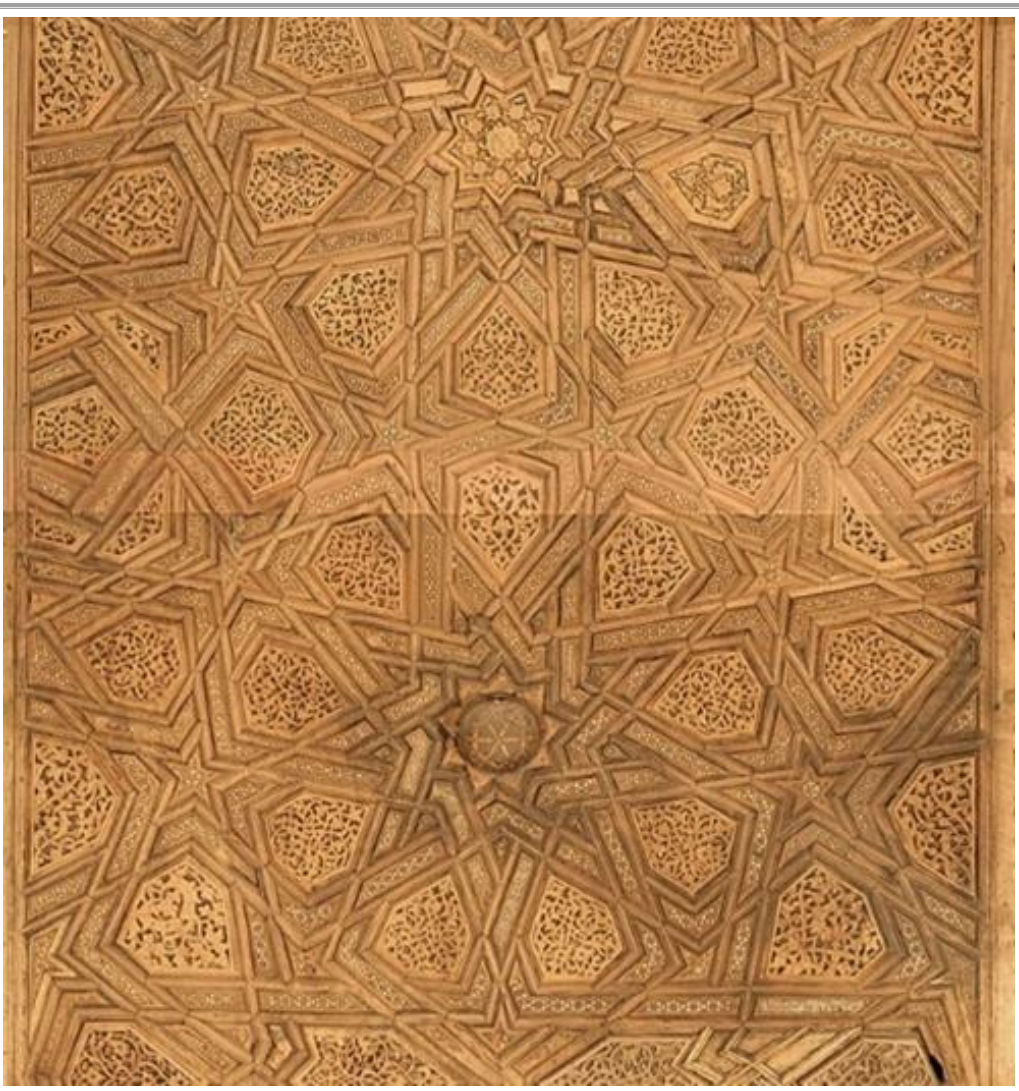

Resim 13: Bursa Ulu Cami Minberi, Doğu Taht Altı Bölümü Ayrıntı (İrteş, 2009, s. 155).

Minber korkulukları kafes tekniğindedir. Kıvrık daldan çıkan rumi bezemeli iki ince şerit arasına yerleștirilmiş olan korkuluklardan doğudakinin geometrik bezemesi tek bir blok halinde devam ederken batıdaki, iki köşedeki yarım panolar hariç ince dikey şeritlerle ayrılan geometrik bezemeli beş panodan oluşmaktadır (Resim 6). Kıvrık dal ve rumi bezemeli bu şeritlerden aşağıdan ikincisi üzerinde ise yukarıda da işaret edildiği üzere sanatçı kitabesi yer alır (Resim 9).

Minberin bir diğer önemli kısmı sultan adını veren bani kitabesinin bulunduğu kapı bölümüdür. Bu bölümün Manisa Ulu Cami minberinden en önemli farkı, taç kısmı ve kitabe panosu dışında tamamının kündekari tekniği ile tasarlanmış olmasıdır (Resim 7) ${ }^{25}$. Bitkisel bezemeli ince bir şeritle ortadaki büyük üç panoya ayrılmış olan kapı kanatlarının künde parçaları üzerinde bitkisel bezeme yer alır. Kapı kanatlarının üzerindeki yatay dikdörtgen pano ise bir kitabe levhasıdır. Sultan adını veren bu kitabe spiraller şeklindeki bitkisel bezemenin üzerindeki sülüs yazı ile geleneği devam ettirmiş olsa da, yazıyı çevreleyen ince şeritteki altıgenlerin yüzeyleri çok ince bir işçilikle uygulanan kakma tekniği farklılık yaratır (Resim 8). Bu durumda da Manisa Ulu Cami minberi ile kıyaslandığında kapı bölümüne tüm gösterişiyle bani kitabesinin hâkim olduğu görülür. Bu kısımdaki tüm düzenleme -kapı kanatları ve kitabe panosu- kündekari tekniğindeki kalın bir şerit ile çevrelenmiştir. Manisa Ulu Cami minberinde de olduğu gibi ajur tekniğindeki taç kısmı rumi, palmet ve kıvrık dallardan oluşan bitkisel bir bezemeye sahiptir. Bu bölüm tepe noktasında bir palmet ile son bulur (Resim 7).

Minberin, dört yönden dilimli kemerli tasarıma sahip olan taht kısmı kafes tekniğinde korkuluklara sahiptir. Kemer köşelikleri ise bitkisel bezemenin uygulandığı ajur tekniğindedir.

${ }^{25}$ Nitekim Selçuklu ve Beylikler döneminde minber kapı sövelerinin de kündekari tekniğinde olduğu başka bir minber bulunmaz (Bayrakal, 2008, s. 67). 
Kemerlerin üzerinde yazı bezemeli birer yatay şerit, onun üzerinde ise her cephede rumi-palmet bezemeli şeritlerin çevrelediği küçük panolar içerisine yerleştirilmiş kemerli düzenlemeler bulunur ${ }^{26}$. İki yan cephedeki yüzeyi/içi boş bırakılmış olan kemerler yenilenmiştir. Tahtın giriş bölümündeki üçlü kemer tasarımının kemer içleri ve köşeliklerinde ajur tekniğiyle bitkisel bezemelerin işlenmiş olduğu görülür (Resim 14). Bu cephede üçlü kemer tasarımının üzerinde de bir yazı kuşağı yer alır. Ancak düz yüzeyli oyma tekniğindeki bu yazı, tekniği ve bitkisel bezeme üzerine yazılmamış olması nedeniyle bu bölümde de bir onarımın varlığını düşündürür (Resim 14). Minberin külahı ajur işçiliği ile oldukça göz alıcıdır. Ters ve düz üçgen parçaların yan yana ve üst üste yerleştirilmesi ile biçimlenmiş olan külahın üst kısmının büyük bir bölümünün yenilenmiş olduğu anlaşılır (Resim 14). Alt kısımdaki özgün parçalar, üçgen yüzeylerinin palmet ve rumilerden oluşan bitkisel bezemeli olduğuna işaret eder. Üst bölümdeki yenilenmiş parçalar ise geometrik bezemelidir. Alt kısımdaki düz yüzeyli oymaya sahip bazı bitkisel bezemeli bazı parçalar da yenilenmiştir.

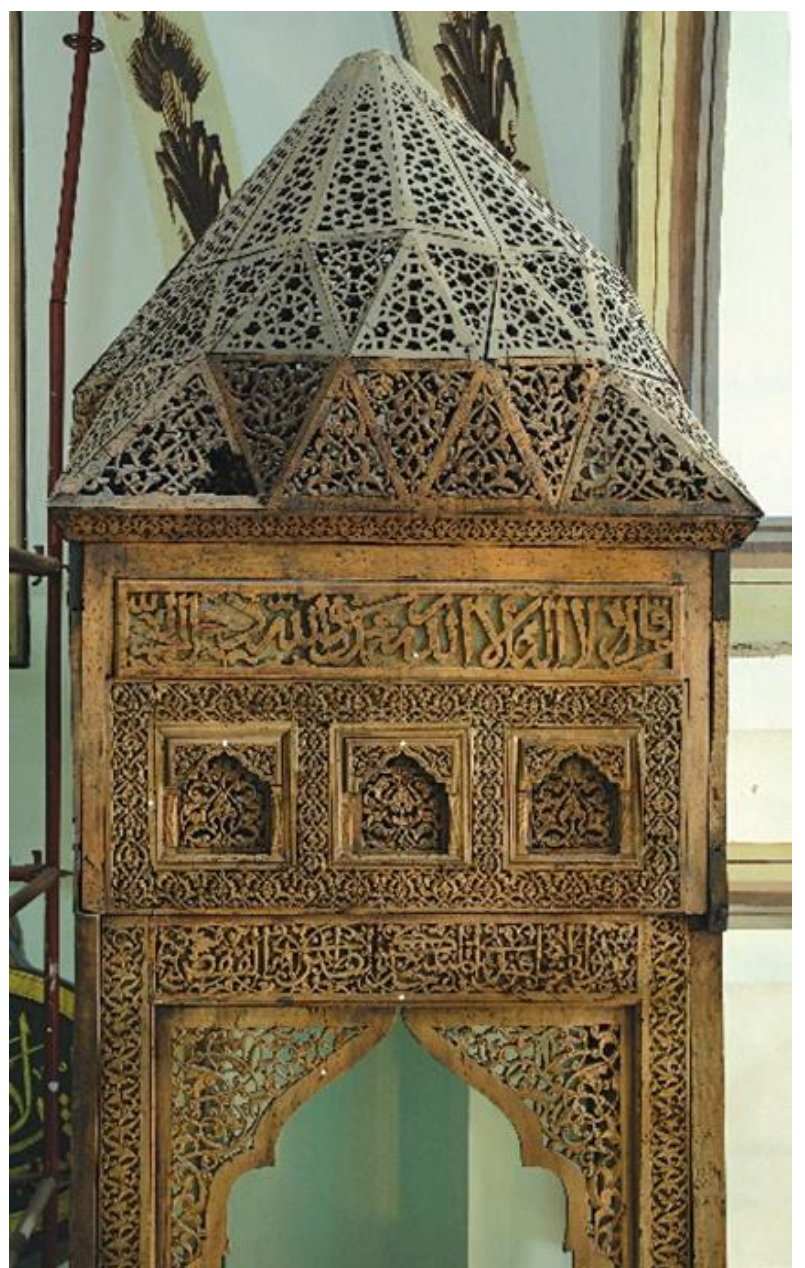

Resim 14: Bursa Ulu Cami Minberi, Taht Bölümü (İrteş, 2009, s. 157).

Görüldüğü üzere teknik, üslup ve kurgu açısından büyük ölçüde Anadolu Selçuklu geleneğini devam ettirmiş olan bu minber anıtsallığl/ölçeği, incelikli kakma işçiliği ve ajur tekniğinin yoğunluğu ile dönemin diğer tüm örneklerini gölgede bırakır. Manisa Ulu Cami minberinde yalnız iki kapı kanadında ve yer yer çok iri parçalar halinde uygulanmış olan kakma tekniği, Bursa Ulu Cami minberinin aynalıklarında çok daha yoğun olmakla birlikte, taht altı bölümleri ile bani kitabesini çevreleyen şeritte ve hepsi oldukça ince bir işçilikle ele alınmıştır. Her iki minber arasında

${ }^{26}$ Bu bölümdeki yazılar için bkz. Tüfekçioğlu, 2001, s. 90 . 
üslup ve kompozisyon açısından büyük benzerlikler bulunmasına karşın, kakma tekniğin yoğunluğu ile sanatının inceliği Bursa Ulu Cami minberini ayrıcalıklı kıldığı kesindir. Nitekim 1640 yılında yapıyı ziyaret eden Evliya Çelebi, minber üzerindeki nakışları, 3. yüzyılda yaşamış ressam Mani'nin resimlediği Erjeng-i Mani kitabındaki rengârenk resimlerin ustalığıyla; oyma işlerini de 16. yüzyıl Osmanlı kâğıt oyma ustası Bursalı Fahri'nin eserleriyle eşdeğer bulur (Evliya Çelebi, 1999, s. 12). Ayrıca, “...cihan ressamları cem 'olsa böyle hurdekârlık etmeğe kâdir değillerdir." (Evliya Çelebi, 1999, s. 12) şeklinde minbere övgüsünü dile getiren seyyah, ilginçtir ki Manisa Ulu Cami minberinden söz dahi etmez.

\section{Sonuç: Siyasi Güç, Sultani Gösteriş ve Minberler}

Bursa Ulu Cami minberinde Evliya Çelebi'nin de överek bitiremediği bu ince işçilik, sanatın kalitesinin yanı sıra banisinin gücüyle bağlantılı maddi olanaklarının da bir yansımasıdır. Bilindiği üzere minberler, üzerlerinde hutbe okunması nedeniyle camilerin en siyasi tarafını simgeler. Eğer bu yapı, Bursa Ulu Cami örneğinde olduğu gibi başkentin merkezinde konumlandırılan bir sultan camisi ise minberin siyasi yönü "imgeye" dönüşür. Edirne Eski Cami (1414) mermer minberinin basamakları dahil tüm yüzeylerinin ince bir işçilikle bezenmesi, minberin "hakimiyet sembolü" olmasıyla ilişkilendirilir (Özbek, 1998, s. 196; 2002, s. 253). Y. Özbek'in "hâkimiyet sembolü" olarak anlamlandırdığı bu imge konumuz özelinde "hükümranlık/güç imgesi" olarak da tanımlanabilir. İlginçtir ki, bu iki minber arasındaki imge çözümlemesinde, sanatsal özelliklere ek olarak en dikkat çekici farklılık, daha önce de ifade edildiği gibi bani kitabeleridir. Manisa Ulu Cami minberindeki sade, gösterişsiz ve dar bir şeride yerleştirilmiş İshak Bey adına karşın, Bursa Ulu Cami minberinde I. Bayezid'in adı çok daha büyük ve gösterişli bir şekilde yazıya dökülmüş ve sultanın adı minber kapı cephesine hâkim kılınmıştır (Resim 2,7-8). Bu farklılık, I. Bayezid'in ölçek ve bezeme olarak dönemin en anıtsal minberini bir "hükümranlık imgesi" olarak anlamlandırdığının en önemli kanıtıdır. Bu durumda da, sözü edilen minberler üzerindeki bani isimlerini veren inşa kitabeleri aslında mimari ve sanatsal özelliklerle de desteklenen dönemin "güçlü kişiliğini”" ele veren en önemli belgelerdir. Minberlere yansıyan bir diğer güçlü bani etkisi sanatçı kitabelerinde kendini gösterir. İlginçtir ki, Manisa Ulu Cami minberinde adını her yönden rahatlıkla görülebilecek şekilde üç farklı noktaya yazabilen sanatçının, Bursa Ulu Cami minberinde sadece bir kitabesi vardır. Bu kitabenin, daha önce de ifade edildiği üzere, adeta bulunduğu noktaya sıkıştırılmış olduğu hatırlandığında, bu farklılığın gücü doruğunda olan bani isteğinin bir sonucu olduğu önerilebilir. Olasılıkla I. Bayezid, hükümranlık imgesi niteliğindeki minberi üzerinde, sanatçı adının kendi adından fazla zikredilmiş olmasını bilinçli olarak engellemiştir.

Minberler arasındaki dönemin güç dengelerini çözümlenmesine yardımcı olan bu sanatsal farklılık camilerin anıtsallıkları, mimari özellikleri ve beyliklerin siyasi güçleriyle desteklenebilir. Camilerdeki merkezi mekânın oluşumuna yönelik kurgunun gelişimi açısından her iki yapı da özel ve üniktir. Çok destekli plan şeması yansıtan Manisa Ulu Cami'nin üç sahına karşılık gelen mihrap önü kubbesi, güney duvar ile birlikte altı serbest destek üzerine oturtulmuştur. İç mekâna büyük ölçüde hâkim olan 10.75 m. çapındaki bu kubbe, camilerdeki merkezi mekân gelişiminin beylikler dönemindeki en önemli adımıdır ${ }^{27}$. Yapı, plan şemasının yanı sıra beden duvarına bitişik medresesi, açık avlusu ve anıtsallığı ile özel bir örnektir. Bursa Ulu Cami ise, klasik dönem Osmanlı sultan camileri gibi hiçbir zaman bani/sultan ismiyle anılmasa da anıtsallığı ve her birimin -çapları 10.89 m. ile $10.27 \mathrm{~m}$. arasında değişen- birer kubbeyle örtüldüğü “eş birimli” plan şeması ile ayrıcalıklıdır. İç mekân tasarımındaki bu şema, başkent Bursa'da Ulu Cami olmak üzere tek bir yapıda uygulanmakla birlikte başkent üslubu içerisinde öne çıkmış ve bazı araştırmacılar tarafından "Ulu Cami Tipi” olarak tanımlanmıştır (Yetkin, 1970, s. 37-46). Bursa Ulu Cami, öncesinde

\footnotetext{
${ }^{27}$ Araştırmacı Suut Kemal Yetkin, toplu, geniş mekân yaratan merkezi mekânlı yapıları, Beylikler döneminin mimariye getirdiği bir yenilik olarak yorumlayarak, bu gelişimi Manisa Ulu Cami ile başlatmaktadır. Bu gelişim, Bursa Ulu ve Edirne Eski camileri ile devam ettirilerek Edirne Üç Şerefeli Camisi'ne ulaşılmaktadır (Yetkin, 1960, s. 258-59).
} 
uygulanmayan bu plan şeması ile birlikte, bugün dahi kent merkezinde yer alan konumu, harimindeki havuzu, minberi ve 1855 depremi sonrasında yenilenen iç mekân yazı bezemeleri ile de döneminin tüm yapılarından ayrilır ${ }^{28}$.

Sözü edilen tüm bu ayrıcalıklı özelliklere karşın, bu iki yapı cephe düzenlemeleri ve malzeme teknik özellikleri bakımından karşılaştııldıklarında da, maddi olanaklara, dolayısıyla da siyasi güce işaret eden çok önemli farklılıklar ortaya koyar. Manisa Ulu Cami cephelerinin, oldukça sade ve özensiz pencere düzenlemelerine karşın, Bursa Ulu Cami cepheleri simetrik yerleştirilmiş çift katlı ve kuzey cephesinde bezemeli pencere düzenlemelerine sahiptir. Manisa Ulu Camisi'ndeki kaba yonu taş/moloz taş inşa malzemesine karşın, Bursa Ulu Camisi'nde düzgün kesme taş ve mermer kullanılmışıı' ${ }^{29}$. I. Bayezid öncesinde sultan yapıları, olasılıkla beyliğin siyasi, coğrafi ve ekonomik koşulları ile ilişkili olarak taş-tuğla almaşık teknikte inşa edilmiştir. I. Bayezid'in prestij yapılarında bu durum değişime uğrar. İnşa malzemesi olarak Bursa Ulu Camisi'nde düzgün kesme taş, Bursa Yıldırım Zaviyesi'nde ise mermer kullanılması, baninin tercihini şekillendiren politik ve ekonomik gücü ile ilişkili olmalıdır. Maddi olanaklar ile doğru orantılı olarak değerlendirebileceğimiz düzgün kesme taş malzemenin, konumu, anıtsallığı ve plan şeması ile oldukça özel olduğu anlaşılan bir yapı için tercihi tesadüf olmasa gerektir. Maddi gücün güçlü ve zengin sultan imajını beraberinde getirdiği düşünülürse, rahatlıkla siyasi anlamda güçlü olanın da maddi gücü elinde bulundurduğu sonucuna ulaş1labilir. O halde, daha önce de işaret edildiği üzere, önemli sayıda mimarlık ürünü ile karşılaşılan bu süreçte kentlere ve beylere göre farklılaşan yapısal dağılım, yönetimsel ve ekonomik gücün mimariye yansımasının bir göstergesidir. $\mathrm{Bu}$ nedenle, konumuzu oluşturan iki bey/sultan karşılaştıııldığında, yapılarındaki sayısal çokluk ve anıtsallık, yapı malzemesi olarak moloz taş yerine düzgün kesme taş ve mermerin kullanılması ile ahşap eserlerdeki ince işçiliğin dönemin siyasi ortamı hakkında ipuçları verdiği yadsınamaz. Siyasal güç ile sanatsal etkinliklerin doğru orantılı olmalarından yola çıkarak, yukarıda işaret ettiğimiz sanatsal değerlerin dönemin daha güçlü kişiliğini de gözler önüne sereceği aşikârdır.

I. Bayezid'in minberler ve mimari özellikler aracılığıyla çözümlenmeye çalışılan güçlü kişiliği ve gücü dönemin siyasi tarihi ile de desteklenebilir. Bir Arap tarihçisi olan İbni Arabşah'ın I. Bayezid için, Balkan dağlarının sınırlarından Erzincan'daki krallıklara kadar Hristiyanların topraklarına boyun eğdirdiğini vurgulayarak bütün Karaman Beyliği ile Menteşe, Saruhan ve diğer Müslüman beyliklerine boyun eğdirdiğini ifade etmiş olması anlamlıdır (Akt. Kafadar, 2010, s. 138). Aslında bu aktarım dönemin siyasi yapısının bir özetidir. I. Bayezid döneminde beylik toprakları, batıda Üsküp, güneyde Atina ve doğuda Bulgaristan Krallı̆̆’nın tamamını kaplayacak şekilde genişletilmiştir. Anadolu'da ise güney bölge, Alanya ve Adana illeri ile Ramazanoğulları'na ait topraklar dışında ele geçirilmiş, doğuda Malatya ve kuzeyde Giresun'a kadar olan bölge Osmanlı hâkimiyeti altına girmiştir (Uzunçarşı11, 2003, s. 263, 278, 297; harita 4). Bu şekilde I. Bayezid Saruhanoğulları ile birlikte Aydın, Menteşe ve Germiyanoğulları beyliklerini de ele geçirmiş olur (Uzunçarş1l1, 1988, s. 84, 88). Bu siyasi gelişmeler, daha önce de ifade edildiği üzere, I. Bayezid'in kitabelerinde görülen "büyük sultanlar sultanı" ve "Arap ve Acem ülkelerinin emîri" sıfatları ile bir

\footnotetext{
${ }^{28}$ Yapının içindeki duvar yazıları ile kubbe bezemeleri 1855 depremi sonrasında yapılmış, duvarlara ünlü hattatların büyük boyda yazı levhaları asılmış ve yine bu onarımda ressam Ferik Tevfik Paşa tarafından caminin mihrap bezemeleri yapılmıştır (Yavaş, 2010, s. 140). Ancak, 17. yüzyılda da payelerin, insan boyu yüksekliğe kadar altın yaldızlı nakışlarla (kalemişi) süslendiğini ve üst kısımlarında ise iri yazıların olduğunu Evliya Çelebi'den öğreniyoruz (Evliya Çelebi, 1999, s. 12).

${ }^{29}$ Selçuklu coğrafyası üzerinde kurulmuş olan Karamanoğulları'nın (1250-1487) İbrahim Bey İmareti (1432-33) gibi anıtsal ölçekli yapılarında moloz taş örgü, kesme taş ise kaplama malzemesidir. Karamanoğulları dışında, Menteşe Beyliğinin (1300-1426) Peçin Ahmet Gazi Medresesi (1378), Balat İlyas Bey Cami (1404) gibi önemli yapılarında da, moloz taş örgü, kesme taş ise kaplama malzemesi olarak tercih edilmiştir. Yine benzer şekilde Aydınoğlu Beyliği'nin (1300-1425) en anıtsal yapısı olan Selçuk İsa Bey (1374) ile Birgi Ulu (1312) camilerinde de kesme taş yapı malzemesi olarak kullanılmış, giriş cepheleri ise mermer ile kaplanmıştır. Bu dönemde moloz taşın kullanılan iki örnekten biri, Eşrefoğulları Beyliğine ait (1280-1326) Beyşehir Eşrefoğlu Cami (1297-99), diğeri ise Saruhanoğullarına ait (1300-1425) Manisa Ulu Camisi'dir (1366).
} 
anlamda da yazıya dökülmüştür. Dönemin beyliklerine ait Birgi Ulu Cami (1312), Selçuk İsa Bey Cami (1374) ve Manisa Ulu Cami (1366) gibi anıtsal örnekler I. Bayezid (1389-1402) öncesinde, bazı beyliklerin "devlet" olma sürecindeki "ulvi” iddialarını belgeler. Ancak Karamanoğulları (12501487) ayrı tutulduğunda, ele geçirilen bu beyliklere ait 15. yüzyıl başlarına tarihlenen anıtsal örneklerin bulunmaması bahsi geçen sürecin mimari üzerinden de okunmasını sağlar.

Görüldüğü üzere tarihi arka plan, bu iki beyliğin siyasal gücünü ve buna bağlı olarak şekillenecek ekonomik yapısını da gözler önüne serer. I. Murad'ın (1360-1389) tahta çıkmasının ardından Osmanlıların diğer beylikler üzerinde denetim kurma çabaları, Germiyanoğullarına ait toprakların bir bölümünü evlilik yoluyla, Hamidoğullarının topraklarını da satın alma yolu ile kendilerine bağlamaları ile son bulmuştur. Buradaki önemli nokta, Osmanlı hazinesinin henüz I. Murad döneminde dahi bir beyliğin topraklarını alacak kadar zengin olduğunun açıkça görünüyor olmasıdır ki bu zenginliğin temel kaynağ ise ganimettir (Emecen, 2000, s. 36-37). Bununla birlikte I. Bayezid'in düğün şenlikleri sırasında, bir Osmanlı uçbeyinin sunduğu değerli ve zengin düğün hediyeleri de Osmanlının ekonomik gücünün bir diğer göstergesi kabul edilir (Emecen, 2000, s. 37).

Peki, Osmanlılar ile Saruhanoğulları arasında nasıl bir ilişkiden söz edebilir. Veriler bu ilişkinin pek dostça olmadığı yönündedir. Saruhanoğullarının, Osmanlılara karşı Aydınoğulları ile birleştikleri, hatta Osmanlıların ittifakta olduğu Kantakuzenos'a karşı İmparatoriçe Anna'yla bir anlaşma yaptıkları dahi bilinmektedir (Emecen, 2000, s. 38). Bununla birlikte Saruhanoğullarının Osmanlılara ek kuvvet olarak Kosova Savaşında (1389) yer almış olması da konumuz açısından önemlidir (Uzunçarşılı, 1988, s. 88). Nitekim bu durum, Saruhan Beyliğinin Osmanlı egemenliğine geçişinin ilk ve en önemli evresi olarak kabul edilmiştir (Emecen, 2000, s. 39). Gerçekten de Saruhanoğulları Beyliği tüm çabalarına karşın, ilk olarak 1390 yılında I. Bayezid tarafindan ele geçirilmiştir. Fetret döneminde (1402-1413) topraklarını geri alan Saruhanoğulları Beyliği son olarak, I. Bayezid'in oğlu I. Mehmed (1413-1421) tarafından Osmanlı Beyliği topraklarına bağlanacaktır (Uzunçarşı1l, 2003, s. 357-359) ${ }^{30}$.

Sonuç olarak, sanatçının, ilk eseri Manisa Ulu Cami minberini "çıraklık”, Bursa Ulu Cami minberini ise "ustalık" eseri olarak nitelemek doğru bir yaklaşım olsa da, bu farklılıkta banilerin oynadığı rolü göz ardı etmek haksızlık olacaktır. Selçuklu sultanları tarafından kendilerine ikta olarak verilen merkezlerde bağımsızlıklarını ilan ederek eşit şartlarda varlıklarını ortaya koyma savaşındaki beyliklerinin başında bulunan her iki kişiliğin de kendisini "sultan" olarak tanımlamalarına karşın, Bursa Ulu Camisi'nin sanatsal inceliğiyle öne çıkan gösterişli minberi, adeta banisi I. Bayezid'in gücünü gözler önüne sermektedir. Bu minberle kıyaslandığında çok daha sade kalan Manisa Ulu Cami minberi ise, İshak Çelebi'nin beyliğine sağlam bir merkez yaratmaya çalışan "bey/sultan" olarak nitelendirilebileceğinin görsel ifadesidir. Öyle görünüyor ki, siyasi güç sultani gösterişi de beraberinde getirmektedir. Yapıların diğer mimari unsurları ile de desteklenerek ortaya konan sonuç, I. Bayezid'in güçlü siyasi kişiliği ve bunu gösterme isteğidir. Saruhanoğlu Beyliğinin ilk olarak I. Bayezid tarafından ele geçirilmesi, Sultan'ın bu beyliği ortadan kaldırılmış olduğunu belgelercesine sanatçısını bilinçli olarak kendi yapısında kullandığını da düşündürür. Bu düşünce, 23 yıl arayla aynı sanatçıya yaptırılan bu iki örnekten sanatsal inceliğiyle öne çıkan Bursa Ulu Cami minberinin dönemin daha güçlü kişiliği ve gücü gösterme isteği görüşünü de destekler. $O$ halde siyasi gücün maddi olanakları, maddi olanakların ise sanatı etkilediği/biçimlendirdiği göz önünde bulundurulduğunda, sözü edilen minberlerin dönemin siyasi ortamı hakkında adeta bir "belge" niteliği taşıdığı kabul edilebilir. Bu şekilde bir tarihçinin Osmanlı beyliği için I. Bayezid'e atfettiği "merkezileştirme ve imparatorluklaştırma hareketi" (Kafadar, 2010, s. 150) şeklinde ifade edilen bu tarihi süreç minberler aracılığıyla ulaşılan sanatsal çıkarımla da okunmuş olur.

\footnotetext{
${ }^{30}$ Sonraki süreçte "Saruhanlı Sancağı" olarak adlandırılan bu bölgenin eski merkezi Manisa ise Amasya'dan sonra diğer bir Şehzade kenti olarak anlam kazanacaktır.
} 


\section{Kaynakça}

Acun, H. (1999). Manisa'da Türk devri yapıları. Türk Tarih Kurumu Basımevi.

Akın, H. (1989). Aydın oğulları tarihi hakkında bir araştırma. Pulhan Matbaası.

Ayverdi, E. Hakkı. (1989) İstanbul mi'mari çağının menşei. Osmanlı mi'marisinin ilk devri. 630805 (1230-1402), İstanbul Fetih Cemiyeti Yayınları.

Bayrakal, S. (2008). Erken dönem Osmanl minberleri. Gökkubbe Yayınları.

Bozkurt, N. (2001). Kakmac1lık. İslam ansiklopedisi. c. 24, Türkiye Diyanet Vakfi. 216-219.

Durukan, A. (2001). Anadolu Selçuklu dönemi kaynakları çerçevesinde baniler. Sanat tarihi defterleri 5, 43-132.

Durukan, A. (2006). Baniler, Anadolu Selçukluları ve beylikler dönemi uygarlı̆̆l, mimarlık ve sanat. 2, A. U. Peker ve K. Bilici (Ed.), T.C. Kültür ve Turizm Bakanlığı Yayınları. 137-171.

Emecen, F. (2000). Osmanlı'nın batı Anadolu Türkmen beylikleri fetih siyaseti: Saruhan Beyliği. Osmanlı Beyliği (1300-1389), E.A. Zachariadou (Ed.), G.Ç. Güven-İ. Yerguz-T. Altınova (Çev), Türk Tarih Vakfı Yayınları. 34-40.

Emecen, F. (2006). Tarih içinde Manisa. Manisa Belediyesi Kültür Yayınları.

Eravc1, M., Korkmaz, M. (1999.). Saruhanoğulları ve Osmanlı klasik döneminde Manisa'da yaşayan kültürel izler. (Ed. Mehmet Çelik), Manisa Valiliği.

Evliya Çelebi. (1999). Evliya Çelebi seyahatnamesi, Topkapı Sarayı Bağdat 304 yazmasının transkripsiyonu-dizini. (Hazırlayan Z. Kurşun, S. A. Kahraman, Y. Dağl1), 2. Kitap, Yap1 Kredi Yayınları.

Gündüz, S. (2010 ). Kitabelere taşınan imgeler: Anadolu Selçuklu-Osmanlı Beyliği örnekleri. XIII. Ortaçă - Türk dönemi kazıları ve sanat tarihi sempozyumu bildirileri 14-16 Ekim 2009, Pamukkale Üniversitesi, Fen-Edebiyat Fakültesi Sanat Tarihi Bölümü Yayınları. 325-332.

Gündüz, S. (2011). Önemli bir siyasi kimlik ve sanatsal kişilik olarak I. Mehmed (1413-1421) ve eserleri. Türkiyat araştırmaları dergisi, 14, 149-172.

Gündüz Küskü, S. (2014). Osmanlı Beyliği mimarisinde Anadolu Selçuklu geleneği. Türk Tarih Kurumu Basımevi.

Gündüz Küskü, S. (2017). Saruhanlı Beyliği dönemi Manisa kent kurgusu üzerine düşünceler. Artsanat, 8, 199-218.

Gündüz Küskü, S. (2017). Bursa kale kentindeki ilk Osmanlı yapıları ve imgesel çözümlemeleri. Osmanlı dünyasında kültürel karşılaşmalar ve sanatsal yansımaları: Prof. Dr. Filiz Yenişehirlioğlu'na armăgan, (Haz. A. P. Şahin Tekinalp, M. F. Müderrisoğlu, Ü. Araç), Hacettepe Üniversitesi Hastaneleri Basımevi. 131-136.

İnalcık, H (2003). Osmanlı İmparatorluğu klasik çağ (1300-1600). (Çev. R. Sezer), Yapı Kredi Yayınları.

İrteş, S. (2009). Ulu Cami'nin son onarımı 2006-2009. Bursa'nın kalbi Ulucami. (Ed. M. Kara, B. Kemikli), Bursa İl Özel İdaresi. 145-163.

Kafadar, C. (2010). İki cihan aresinde, Osmanlı Devletinin kuruluşu. (Çev. Ceren Çıkın), (Haz. Mehmed Öz), Birleşik Yayınevi.

Karamağaralı, H. (1955). Anadolu'da beylikler devri minberleri. (Yayımlanmamış doktora tezi) Ankara Üniversitesi, İlahiyat Fakültesi. 
Karamağaralı, H. (1964-65). Çorum Ulu Camiindeki minber. Sanat tarihi yıllı̆̆

Konyal1, İ. H. (1967). Abideleri ve kitabeleri ile Karaman tarihi. Baha Matbaas1. 71-72, 97-99.

Oral, M. Z. (1962). Anadolu'da san'at değeri olan ahşap minberler, kitabeleri ve tarihçeleri. Vakıflar dergisi, 5, s. 23-77.

Özbek, Y. (1998). The minber of Edirne Old Mosque. Architectures des Demeures, Inscriptions Funéraires et Dynamique de Restauration (Préface du. A. Temimi). 193-202.

Özbek, Y. (2002). Osmanlı Beyliği mimarisinde taş süsleme (1300-1453). Türk Tarih Kurumu Basimevi.

Özönder, H. (1985). Karamanoğlu İmareti ve vakfiyesi. II. Vakıf haftası 3-9 Aralık 1984, (konuşmalar ve tebliğler), Vakıflar Genel Müdürlüğü Yayınları. 127-128.

Sevim, S., Öcalan, H. B. (2010). Osmanlı kuruluş devri vakfiyeleri. Osmangazi Belediyesi Yayınları.

Sönmez, Z. (1995). Başlangıcından 16. yüzyıla kadar Anadolu Türk mimarisinde sanatçılar. Türk Tarih Kurumu Basımevi.

Tüfekçioğlu, A. (2001). Erken dönem Osmanlı mimarisinde yazı. Başbakanlık Basımevi.

Uzluk, F. N. (1969). Germiyanoğlu Yakub II. Bey'in vakfiyesi. Vakıflar dergisi, Sayı: VIII. 88, 92.

Uzunçarşı11, İ. H. (1938). 14-15. Asırlarda Anadolu Beyliklerinde toprak ve halk idaresi. Belleten, II, 97-145.

Uzunçarşı11, İ. H. (2003). Osmanlı tarihi. I, Türk Tarih Kurumu Basımevi, (8.bask1).

Uzunçarş1lı, İ. H. (1988). Anadolu Beylikleri ve Akkoyunlu, Karakoyunlu devletleri. Türk Tarih Kurumu Yayınları.

Uzunçarş1l1, İ. H. (1929). Kitabeler ve Sahip, Saruhan, Aydın, Menteşe, İnanç, Hamid oğulları hakkında malumat. II, İstanbul.

Yavaş, D. (2009). Ulucami'nin geçirdiği tamirler. Bursa'nın kalbi Ulucami. (Ed. M. Kara, B. Kemikli), Bursa İl Özel İdaresi. 138-144.

Yetkin, S. K. (1960). Beylikler devri sanatından klasik Türk sanatına. V. Türk tarih kongresi. 257266.

Yetkin, S. K. (1970). Türk mimarisi. Bilgi Yayınevi. 